\title{
DIVERSE NEW MICROVERTEBRATE ASSEMBLAGE FROM THE UPPER TRIASSIC CUMNOCK FORMATION, SANFORD SUBBASIN, NORTH CAROLINA, USA
}

\author{
ANDREW B. HECKERT, ${ }^{1}$ JONATHAN S. MITCHELL, ${ }^{1,2}$ VINCENT P. SCHNEIDER, ${ }^{3}$ AND PAUL E. OLSEN ${ }^{4}$ \\ ${ }^{1}$ Department of Geology, Appalachian State University, ASU Box 32067, Boone, NC 28608-2067, USA, heckertab@appstate.edu ; \\ ${ }^{2}$ Committee on Evolutionary Biology, University of Chicago, 1025 E 57th St, Chicago, IL 60637, USA, mitchelljs@uchicago.edu ; \\ ${ }^{3}$ North Carolina Museum of Natural Sciences, 11 West Jones Street, Raleigh, NC 27601-1079, USA, vince.schneider@ncdenr.gov ; and \\ ${ }^{4}$ Lamont Doherty Earth Observatory, 61 Rt. 9W Palisades, NY 10964-1000, USA, polsen@ldeo.columbia.edu
}

\begin{abstract}
The Moncure microvertebrate locality in the Cumnock Formation, Sanford sub-basin, North Carolina, dramatically increases the known Late Triassic age vertebrate assemblage from the Deep River Basin. The $\sim 50,000$ recovered microvertebrate fossils include osteichthyans, amphibians, and numerous lepidosauromorph, archosauriform, and synapsid amniotes. Actinopterygian fossils consist of thousands of scales, teeth, skull, and lower jaw fragments, principally of redfieldiids and semionotids. Non-tetrapod sarcopterygians include the dipnoan Arganodus sp., the first record of lungfish in the Newark Supergroup. Temnospondyls are comparatively rare but the preserved centra, teeth, and skull fragments probably represent small (juvenile) metoposaurids. Two fragmentary teeth are assigned to the unusual reptile Colognathus obscurus (Case). Poorly preserved but intriguing records include acrodont and pleurodont jaw fragments tentatively assigned to lepidosaurs. Among the archosauriform teeth is a taxon distinct from $R$. callenderi that we assign to Revueltosaurus olseni new combination, a morphotype best assigned to cf. Galtonia, the first Newark Supergroup record of Crosbysaurus sp., and several other archosauriform tooth morphotypes, as well as grooved teeth assigned to the recently named species Uatchitodon schneideri. Synapsids represented by molariform teeth include both "traversodontids" assigned to aff. Boreogomphodon and the "dromatheriid" Microconodon. These records are biogeographically important, with many new records for the Cumnock Formation and/or the Newark Supergroup. In particular, Colognathus, Crosbysaurus, and Uatchitodon are known from basins of Adamanian age in the southwestern U.S.A. These new records include microvertebrate taxa more typical of non-Newark basins (abundant archosauriforms, temnospondyls, lungfish) as well as more typical Newark osteichthyans and synapsid-rich faunal elements.
\end{abstract}

\section{INTRODUCTION}

$\mathrm{D}$ URING THE Triassic nonmarine tetrapod faunas underwent extensive changes from those dominated by temnospondyl amphibians, procolophonids, dicynodonts, and cynodonts in the Early Triassic to faunas composed primarily of diapsids and mammals by Jurassic time. Over this same interval numerous clades, including lissamphibians, turtles, pterosaurs, lepidosaurs, dinosaurs, and mammals all made very early or first appearances (Sues and Fraser, 2010; see also reviews by Fraser, 2000, 2006). In spite of numerous studies of Triassic assemblages across Pangea, one of the prevailing problems in studying this transition is that most localities yield paucispecific assemblages limited to just a few of these groups. This is particularly true in North America, where western assemblages of Late Triassic age are dominated by archosaurs and temnospondyls (e.g., Long and Murry, 1995) with few synapsids, even when including microvertebrates (Lucas and Luo, 1993; Heckert, 2004). Even in the eastern part of the continent where the Newark Supergroup has both archosaur- and synapsid-dominated assemblages in the Triassic (e.g., Olsen, 1988; Sues and Olsen, 1990; Sues et al., 1994) and Jurassic (Olsen et al., 1987; Shubin et al., 1994) portions of the section, most localities are low in diversity and do not contain representatives of both diapsid and synapsid taxa. Here we report an extremely diverse microvertebrate assemblage from a locality in Late Triassic age strata in the Deep River Basin of North Carolina that yields abundant fossils of a variety of osteichthyans, multiple archosauromorphs, lepidosauromorphs, and synapsids. In this paper we provide a detailed description of the tetrapod assemblage to facilitate future comparisons and demonstrate how discovery of a single microvertebrate locality can greatly increase the known diversity of even a well-studied depositional system.

Institutional abbreviations used here include: NCSM, North Carolina Museum of Natural Sciences, Raleigh; YPM, Yale Peabody Museum, New Haven, Connecticut.

\section{MATERIALS AND METHODS}

All of the fossils described here were obtained either from surface collecting or by screenwashing small ( $250 \mathrm{~kg}$ total) samples of fossiliferous matrix, collected over intermittent visits to a small site from 2001 to 2008. The productive horizon at the locality (NCSM Paleo 1904; see below) is extremely thin and restricted to no more than 2 to $3 \mathrm{~m}$ laterally. Matrix was carefully screenwashed through nested brass sieves at the NCSM. Matrix collected in the two smallest sieves, $1.18 \mathrm{~mm}$ and $600 \mu \mathrm{m}$, was dried and examined while that collected in the $2.0 \mathrm{~mm}$ sieve was further broken down in a $10 \%$ acetic acid solution. The resulting concentrate was examined under light microscopes, but best results were obtained by separating lighter concentrate from fossils using sodium polytungstate in a method adapted from Cifelli et al. (1996) and described by Mitchell and Heckert (2010), which increased the percentage of fossils in the concentrate from $1 \%$ to $17 \%$ of the grains. All scanning electron micrographs (SEM images) were obtained using a Quanta 200 ESEM utilizing XT microscope server imaging software, with subsequent image manipulation performed in various versions of Adobe Photoshop ${ }^{\circledR}$ CS.

Ranks within the systematic paleontology section follow Benton (2005), although the use of ranks has generally fallen 


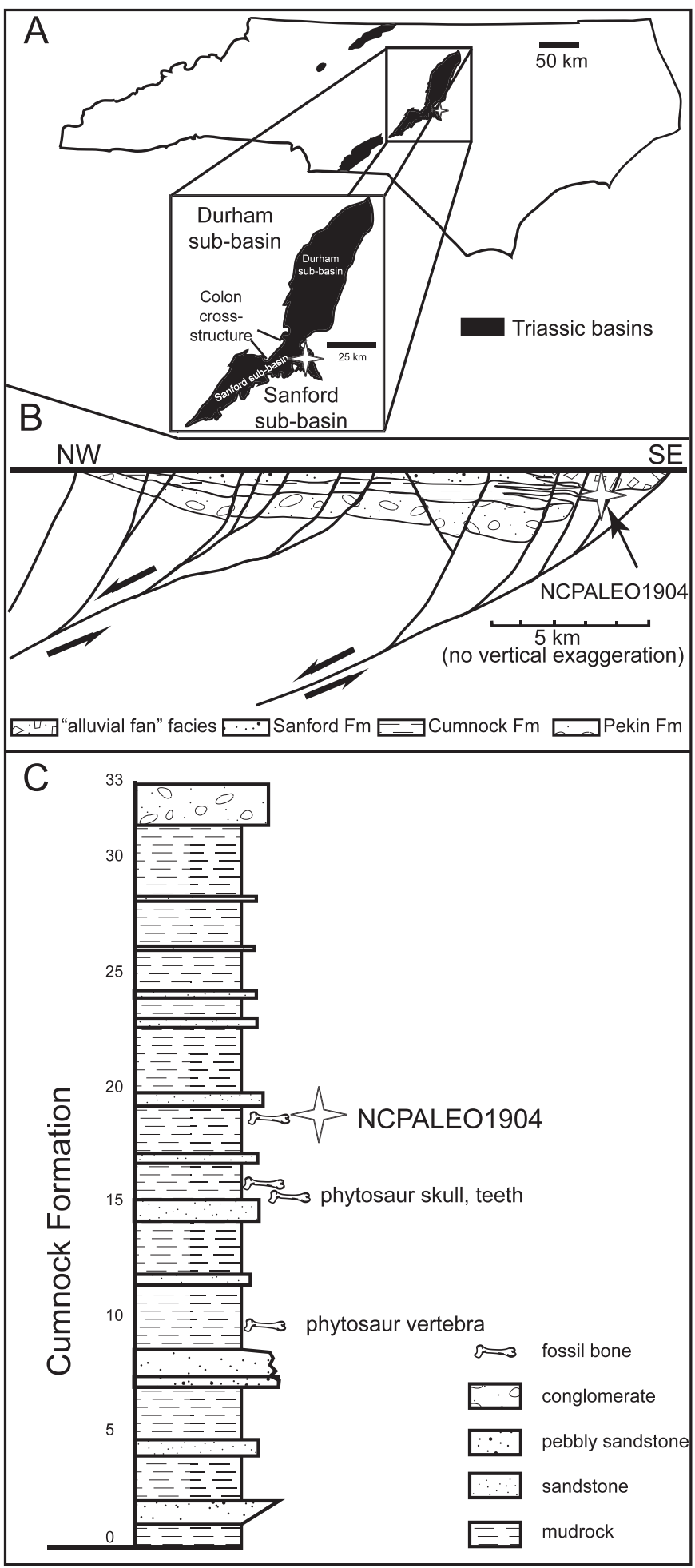

FIGURE 1 - Index map, cross-section, and stratigraphic section showing the geographic location and stratigraphic position of locality NCPALEO1904. $A$, index map; $B$, cross-section showing basin-margin position of NCPALEO1904 (modified from Olsen et al., 1991, fig. 9.4); $C$, stratigraphic section showing position of locality $14 \mathrm{~m}$ below top of exposure.

out of favor in the vertebrate paleontological community. The phylogeny behind them is based on that used by Heckert (2004), with some modification due to updated phylogenies, particularly in the case of archosaurs (e.g., Brusatte et al., 2010; Nesbitt, 2011) and cynodonts (Liu and Olsen, 2010; Sues and Hopson, 2010). Open nomenclature (e.g., aff., cf., etc.) to describe the level of uncertainty in some identifications follows the guidelines of Bengston (1988). Description of teeth here follows precedents established for the relevant taxa. Thus, for archosaurs we follow Currie et al. (1990) and Farlow et al. (1991), with the caveat that we use TCL (total crown length) and TCH (total crown height) following Heckert (2004) rather than, for example, FABL (fore-aft basal length of Farlow et al., 1991). When describing synapsid teeth we follow Hopson (1971) and later authors (Sues, 2001; Liu, 2007; Sues and Hopson, 2010). All specimens are reposited at the NCSM. Some specimens are referred to explicitly in the text and figure captions, these and other key supporting specimens are listed in the Appendix.

\section{GEOLOGICAL SETTING}

The site described here is designated NCSM locality NCPALEO1904 and it lies on the east flank of a quarry operation near Moncure in Chatham County, North Carolina (detailed locality data are on file at NCSM) (Fig. 1). Strata exposed at the quarry consisted of $\sim 33 \mathrm{~m}$ of "red-bed" siliciclastics at the time the stratigraphic section was measured (Fig. 1C); since that time additional excavations have exposed more, lithologically similar, strata downsection. Exposed strata consist principally of red and purple mudstone and thin ( $1.5 \mathrm{~m}$ thick) lenses of red and gray siltstone and sandstone that strike to the northeast and dip $\sim 20^{\circ}$ to the southeast. The fossils documented here occur in a thin lens of purplish gray, pedogenically modified siltstone, $\sim 14 \mathrm{~m}$ below the top of exposure locally (Fig. 1C). The site appears to be extremely localized, with the productive zone no more than $3 \mathrm{~m}$ across and very thin. Surface collecting was restricted to a $3 \mathrm{~m}$ by $1 \mathrm{~m}$ area.

Strata at the Moncure site belong to the Newark Supergroup (Olsen, 1978), deposited in a series of rift basins extending from the present-day Gulf Coast to Canada. In North Carolina, the easternmost of these basins exposed at the surface is the Deep River basin, which is subdivided into the northern Durham, the central Sanford, and the southern Wadesboro sub-basins (Olsen et al., 1991), all of which contain Triassic age sedimentary rocks assigned to the Chatham Group (Emmons, 1857; Olsen, 1977, 1978; Weems and Olsen, 1997). The Moncure locality is in the northern Sanford sub-basin just south of the Colon cross-structure, a basement feature that separates it from the Durham sub-basin to the north (Olsen et al., 1991; Fig. 1A).

Vegetative cover and lateral changes in facies complicate the stratigraphic assignment of this section within the Chatham Group, which we argue are largely equivalent to the upper Cumnock Formation. Campbell and Kimball's (1923) stratigraphy of the area includes a tripartite subdivision of two predominantly red, sandstone-dominated units (Sanford and Pekin formations) above and below, respectively, a middle, predominantly gray, fine-grained unit, the Cumnock Formation. Reinemund (1955) mapped the area where the current quarry is located as Sanford Formation based largely on the presence of predominantly red strata in this region that, based on the map pattern, should lie stratigraphically above a thin interval of gray strata that Reinemund mapped as Cumnock Formaton. Olsen et al. (1991) recognized that at least some of Reinemund's (1955) basal Sanford Formation strata are in fact laterally equivalent to Cumnock Formation strata, especially away from the central Sanford subbasin (Olsen et al., 1991) (Fig. 1B). More recently, Whiteside et al. (2011) used core samples and paleomagnetic data to document the lateral 
change of gray and black upper Cumnock Formation in the central Sanford subbasin to red, purple, and gray strata laterally, in what is mapped as Sanford Formation. Therefore, we consider the locality to lie in the predominantly red and gray facies of the Cumnock Formation where local red coloration caused Reinemund (1955) to assign them to the lower Sanford Formation.

Chatham Group strata have long been recognized as Late Triassic in age, and most workers have assigned the Cumnock Formation and equivalent strata an early Late Triassic (Carnian) age based on palynology (Cornet, 1993; Litwin and Ash, 1993) and vertebrate biostratigraphy (Olsen et al., 1991; Huber et al., 1993a; Lucas and Huber, 2003). Olsen (1997) assigned almost all Chatham Group rocks to his third of four Newark Supergroup tectonosequences (TS-III) but Olsen and Huber (1997) subsequently assigned all but the uppermost Pekin Formation to TS-II based on the map pattern of conglomerate units in the Pekin indicating an apparent significant unconformity. All the strata in Deep River basin which were considered then to range from late Carnian to Norian age, record deposition from $\sim 230-219$ Ma (Olsen, 1997, fig. 3). More recent work demonstrates that much of the purportedly Carnian nomarine strata is in fact Norian in age as the base of the Norian stage is approximately $228 \mathrm{Ma}$ (Muttoni et al., 2004; Furin et al., 2006; Olsen et al., 2011). Therefore, the strata exposed at Moncure are most likely early Norian in age, or about 225 Ma (Whiteside et al., 2011).

\section{FAUNAL DESCRIPTION}

Presently the collection of fossils from this site includes approximately 50,000 specimens, the vast majority of which are fish scales (principally redfieldiids and semionotids) and unidentifiable bone fragments. The more informative fossils represent a wide array of taxa, including lungfish and diverse amniotes. Although some of the bigger specimens represent larger taxa (e.g., "rauisuchians"), very few of the recovered specimens are more than $1 \mathrm{~cm}$ in maximum dimension, and most of the non-dental tetrapod elements are small fragments of ribs, limbs, and vertebrae that are generally not diagnostic.

Microvertebrate assemblages such as this pose numerous problems related to fossil identification (see review by Baszio, 2008). Beyond the obvious problems associated with fragmentary fossils, loss of association, faunal mixing, and time averaging, many Mesozoic nonmarine assemblages are rendered more complex by the relatively unspecialized nature of common fossils (e.g., archosauriform teeth) compared to common fossils in younger assemblages (e.g., Cenozoic mammal teeth). Recently some authors have maintained that identification of fragmentary fossils is only viable using an apomorphy-based approach with taxonomic assignments "based on homology and limited to observable synapomorphies" (e.g., Nesbitt and Stocker, 2008, p. 1069). While such attempts are laudable, we cannot embrace this methodology for several reasons. First and foremost, many microvertebrate taxa are only known from screenwashed or other assemblages of fragmentary remains, and thus no reliable phylogeny exists for these taxa. Second, even for contemporaneous taxa for which phylogenies exist, the "apomorphy-based" approach introduces all of the inherent assumptions of the phylogeny, including character selection (and omission), character variability (individual, sexual, ontogenetic, etc) and, critically, character polarization. Furthermore the apomorphy-based approach is jeopardized because: 1) relevant phylogenies are frequently revised, so the stability of topology is a serious concern; 2) not all microvertebrate taxa are of equal interest to phylogeneticists, such that there are literally dozens of cladistic phylogenies incorporating basal archosaurs but only one for Mesozoic dipnoans (Cavin et al., 2007) and none for Mesozoic semionotids since the Newark Supergroup work of McCune (1987); and 3) because of the nature of cladistic analysis, especially the tendency for large numbers of characters to be concentrated in small anatomical regions (e.g., skulls) that are unlikely to be preserved in microvertebrate assemblages, selected apomorphies in other elements may be "dragged" up or down the tree based on character states elsewhere in the body. Thus, distinctive anatomy at the microvertebrate level may be artificially construed as either more plesiomorphic or derived based on an analysis of more complete specimens.

We consider any taxonomic assignment a hypothesis, and we advocate a "nested hypothesis" approach. Namely, for each element, a taxon is ascribed using apomorphic assessment to the lowest rank possible, and then this assessment is further refined using gross morphology (which is, effectively, a description of character state combinations) and, most provisionally, stratigraphic and geographic data. Elements may be referable to one of several clades based on independent acquisition of an apomorphy, yet if only one of those clades is known from the unit, and the overall morphology of the element is more consistent with members of this clade, we argue that a provisional taxonomic assignment to a finer level than can be determined solely from the apomorphy is reasonable, so long as the rationale is clear. Gross similarity and stratigraphic distribution for clades certainly changes with increased sampling, but so does the distribution of character states, and characters thought to be apomorphic often turn up convergently in other taxa (e.g., Parker et al., 2005). No method of assignment is perfect, and because of this we prefer the multifaceted approach, where sampling is dense, as opposed to a solely apomorphic one that ignores all other sources of data.

In the following paragraphs we briefly detail our taxonomic assignments of some of the more diagnostic and informative specimens, especially those that are new records for the Chatham Group and/or the Newark Supergroup. For a complete faunal list see Table 1, which also indicates the level to which various taxa represent new records. The Appendix contains a list of the most diagnostic referred specimens.

\section{SYSTEMATIC PALEONTOLOGY}

Class Osteichthyes Huxley, 1880

Subclass ACTINOPTERYGII Klein, 1885

Superdivision CHONDROSTEI Müller, 1844

Order REDFIELDIIFORMES Berg, 1940

Family REDFIELDIIDAE Berg, 1940

Redfieldiidae indet.

Figure 2.2-2.4

We tentatively interpret some of the scales as those of redfieldiid fish. These scales are rhomboid, essentially smooth, and have a slightly convex leading edge that articulates with a shallow concavity in the next most anterior scale (NCSM 25015, 25717-25719; Fig. 2.2-2.4). These are the characteristics Murry $(1986,1989)$ identified as diagnostic of redfieldiids, especially Cionichthys and the Synorichthys/Lasalichthys species complex (Schaeffer, 1967). Other scales with discontinuous ridges are similar to those of Synorichthys as illustrated by Schaeffer and Mangus (1970, pl. 6). Olsen et al. (1982) previously documented redfieldiid pectoral spines, skull bones, and scales from the Cumnock Formation of the more central Sanford basin from coal mine tailings. 
TABLE 1 - The vertebrate fauna of the Moncure locality.

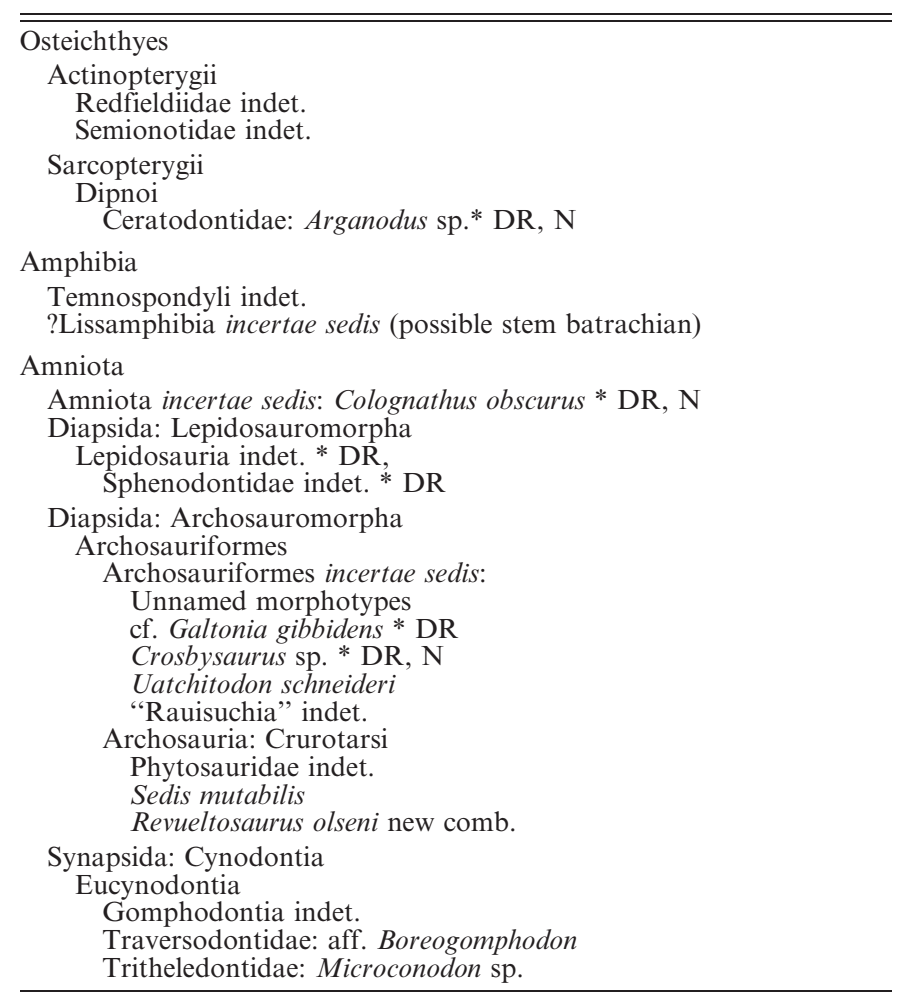

* new record for Cumnock Formation.

DR new record for Deep River Basin.

$\mathrm{N}$ new record for Newark Supergroup.

Superdivision NeOPTERYGII Regan, 1923

Order SEMIONOTIFORMES Arambourg and Bertin, 1958

Family SEMIONOTIDAE Woodward, 1890

Semionotidae indet.

Figure 3.1, 3.2

Most of the osteichthyan fossils recovered from the Moncure locality are isolated scales, scale fragments, and dentulous bone fragments. Scale textures range from essentially smooth to heavily textured with longitudinal grooves, ridges, and pits. The mostly smooth versions of these likely represent those of semionotid fish, based on the presence of a characteristic kind of "peg-and-socket" articulation (NCSM 25696 and 25697; Fig. 3.1, 3.2). These scales tend to be less rhomboid and less ornamented than those of the redfieldiids identified previously. Semionotid scales, especially the dorsal ridge scales, possess pegand-socket articulations, with a large second process making them particularly diagnostic (McCune, 1987; cf., Grande, 2010).

\section{Subclass ACTINOPTERYGII Klein, 1885 \\ Actinopterygii indet. \\ Figures 2.1, 2.5-2.12}

The majority of Moncure osteichthyan scales and bone fragments, while diverse, are not diagnostic below the level of Actinopterygii. One particularly well-preserved scale (NCSM 25695, Fig. 2.1) appears to preserve the original iridescence of the enameloid. Many others (e.g., Fig. 2.5-2.12) represent an array of morphotypes ranging from nearly smooth (Fig. 2.6) to extensively ornamented with a variety of ridges (e.g., Fig. 2.8, $2.9,2.12$ ). Additionally, dentigerous skull and jaw fragments are common. One such element (NCSM 24735, Fig. 3.5) is typical in preserving parts of two teeth on a heavily ornamented bone fragment with enameloid on the outer surface.
Some of the ridged scales may pertain to redfieldiids, especially Synorichthys (Schaeffer and Mangus, 1970), but none seem to be referable to Turseodus or any basal palaeonsiciform known from younger Norian age strata in the Durham subbasin of the Deep River basin (Olsen, 1977; Olsen et al., 1982) or other Newark Supergroup basins. However, without detailed work on more complete specimens, assigning these to more inclusive clades is not feasible. We consider 45,000 scales, teeth, and bone fragments of indeterminate actinopterygians to be a reasonable minimum estimate for the number of such fragments, which therefore comprise $\sim 90 \%$ of the collected fossils.

\section{Subclass SARCOPTERYGII Romer, 1955 Order DIPNOI Müller, 1844 \\ Family Ceratodontidae Gill, 1872 \\ Genus Arganodus Martin, 1979 \\ ARgANODUS sp. \\ Figure 3.6, 3.7}

The Moncure site is the first Newark Supergroup locality to yield lungfish fossils, in this case eight essentially complete and 18 more incomplete dental plates and numerous dental plate fragments representing both pterygoid and splenial dental plates. The specimens we describe here most closely resemble Arganodus dorotheae (Case, 1921), a relatively diminutive species from the Late Triassic age strata of the American Southwest (e.g., Murry, 1989), but are even smaller. All are minute ( 3 to $8 \mathrm{~mm}$ maximum dimension) and possess 6 to 7 sharp (cutting, not crushing) ridges radiating through $\sim 120^{\circ}$ from the mesial corner (Fig. 3.6, 3.7). Key biometric values for lungfish tooth taxonomy include the angle between the mesial (anterior-most) and lingual (posterior-most) sides, as well as between the line of each crest and that of the most lingual crest (e.g., Murry, 1989). Unfortunately, many of the Moncure specimens are missing either the mesial or lingual crest, rendering measurement difficult. The complete angles we have been able to measure, along with reasonable extrapolations of less complete material, preliminarily support the affinity of the Moncure specimens with Arganodus dorotheae (Table 2; see Murry, 1989).

Kemp (1998) assigned the type species of Arganodus, A. atlantis Martin 1979 to Asiatoceratodus but Cavin et al. (2007) rejected the synonymy of Asiatoceratodus with Arganodus and retained the latter as a distinct genus. Both Kemp (1998) and Cavin et al. (2007) focused primarily on the osteology of the skull, of which there are no Late Triassic age materials from Moncure or the American Southwest, although Cavin et al. (2007) did find and code differences between the toothplates of Asiatoceratodus and Arganodus (see also Soto and Perea, 2010, table 1). In particular, Cavin et al. (2007) considered the fact that the first ridge of upper toothplates in Arganodus atlantis is longer than the lingual margin of the toothplate, and the presence of a contact between the two lower toothplates, as derived characteristics. The Moncure specimens, as well as Arganodus specimens from the Triassic of the American Southwest share the first character but their isolated nature obscures the nature of a contact between the teeth; although Murry (1989) considered the teeth from the southwestern U.S.A. to possess a contact between the upper toothplates but largely lack one between the lower toothplates. The Moncure toothplates are only approximately half the linear dimensions of typical Arganodus dorotheae specimens. Some Moncure specimens retain the well-preserved tubercles and other textures associated with ontogenetically young lungfish (NCSM 20743, Fig. 3.7), but others of similar size are more worn, with the tubercles ground down as is often seen in more mature specimens of other lungfish (NCSM 20742, Fig. 3.6). Because the preserved rows are worn but the edges of these 

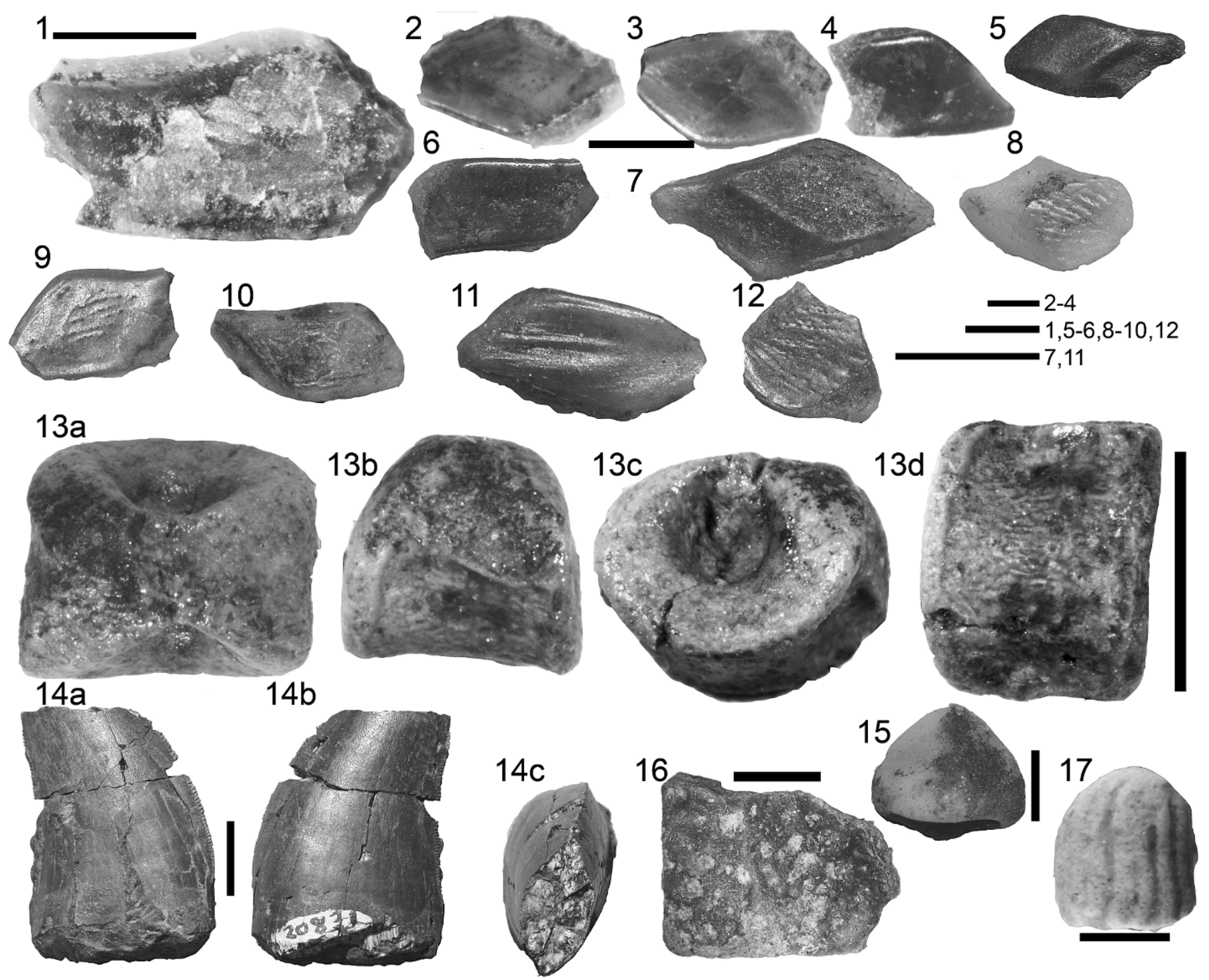

FIGURE 2-Digital photomicrographs $(1-13,15-17)$ and digital photographs (14) of representative vertebrate fossils from the Moncure locality, Cumnock Formation, North Carolina. 1-12, representative osteichthyan scales, all in external view: 1, well preserved scale (NCSM 25695) showing reflective (iridescent) original enameloid; 2-4 typical "redfieldiid-grade" scales (NCSM 25717-25719, respectively); 5-12 variety of actinopterygian scales showing range of shapes, textures, and variation in ridges common at the Moncure locality: 5, NCSM 25707; 6, NCSM 25712; 7, NCSM 25710; 8, NCSM 25702; 9, NCSM 25711; 10 , NCSM 25700; 11 , NCSM 25714; 12, NCSM 25715; 13 stereospondyl (metoposaur?) centrum (NCSM 23585) in $a$, dorsal; $b$, lateral; $c$, anterior?; $d$, ventral view; 14, tooth of a large "rauisuchian" (Archosauriformes indet.)(NCSM 20831) in $a$, lingual; $b$, labial; $c$, occlusal view; 15 , Archosauriformes indet. enamel-less (digested?) tooth (NCSM 25719) in labial view; 16, Archosauriform osteoderm (NCSM 23290) similar to those of Revueltosaurus in external (dorsal?) view; 17, representative small coprolite (NCSM 25720). Scales $1 \mathrm{~mm}(1-12,15), 5 \mathrm{~mm}(13), 1 \mathrm{~cm}(14)$ and $2 \mathrm{~mm}(16,17)$.

specimens are not rounded off, we thus we consider it possible that they may represent a distinct, diminutive species. Therefore, because the Moncure teeth appear to share the derived conditions exhibited by Arganodus atlantis described by Cavin et al. (2007) we refer them to Arganodus but refrain from assigning them to species until more diagnostic material is recovered. Because lungfish have only four teeth in the dentition, and these teeth are not replaced, the approximately 30 specimens here represent several individuals.

Class AMPHIBIA Linnaeus, 1758

Order TEMNOSPONDYLI Zittel, 1888

Suborder STEREOSPONDYLI Fraas, 1889

Stereospondyli incertae sedis

Figures 2.13, 3.8

Amphibian fossils are relatively rare at Moncure, and are represented by only a few dozen teeth, textured bone fragments, and five stereospondylous vertebrae. Approximately 60 teeth we consider temnospondyl are small and labyrinthodont, and some textured bone fragments likely pertain to the skulls or pectoral elements of metoposaurs. The vertebrae are small, proportionately elongate, simple, and spool-shaped with a diameter:length (articular width:centrum length) ratio of 1.2:1 (NCSM 23585, Fig. 2.13). Centra of the small metoposaurid Apachesaurus and the larger Dutuitosaurus are relatively long, with a diameter:length ratio of less than 0.8, (Hunt, 1993) so this centrum probably does not pertain to these taxa. We also illustrate a typical small, recurved labyrinthodont tooth (NCSM 23566, Fig. 3.8). Labyrinthodont dentitions are widely distributed in space and time but temnospondyl taxa from strata of similar age in the Newark Supergroup are exclusively metoposaurs. We therefore consider these fossils to likely represent metoposaurid amphibians, as non-metoposaurid amphibians in the 
Newark Supergroup are extremely rare and limited to the older parts of the section (Olsen, 1988; Milner, 1994; Olsen and Rainforth, 2003). Because of the large number of teeth in temnospondyl jaws, even small ones (e.g., Davidow-Henry, 1989; Zanno et al., 2002), it is possible, albeit unlikely, that these fossils represent a single individual.

\section{Amphibia incertae sedis \\ Figure 3.9, 3.10}

Several enigmatic bones with possible lissamphibian affinities were recovered from the Moncure locality. These include several anteriorly expanded ilia with antero-dorsally deflected acetabula (e.g., NCSM 25164, Fig. 3.10) and an atlas (NCSM 25232) with two cotyles and a tuberculum interglenoideum (Fig. 3.9). This atlas indicates the presence of a dissorophid amphibian, possibly phylogenetically bracketed by Gerobatrachus, Triadobatrachus and salamanders, and the anteriorly expanded ilium likely indicates the presence of a frog-line batrachian.

Two atlanteal cotyles on the atlas are known both in certain groups of 'Amphibia' and derived cynodonts, although cynodonts have multiple ossifications that articulate to form their atlas (Jenkins, 1970). A tuberculum interglenoideum ("odontoid" process) is only present in stem caecilians (Evans and Sigogneau-Russell, 2001), salamanders, some Permian temnospondyls, and the amphibamid temnospondyl Gerobatrachus hottoni (Anderson et al., 2008). Given that Gerobatrachus was recently recovered as the outgroup of the frog + salamander clade ( Batrachia), and that both Gerobatrachus and salamanders share a tuberculum interglenoideum, it is either a primitive trait for the Batrachia + Gerobatrachus clade and lost among the salientians, or acquired convergently by Gerobatrachus and caudates. Neither Triadobatrachus nor Czatkobatrachus possess this feature of the atlas (Evans and Borsuk-Bialynicka, 2009), which supports the caudateGerobatrachus convergence hypothesis, but not to the exclusion of the alternative.

Possible lissamphibian ilia from the Moncure site are well represented by NCSM 25164 (Fig. 3.10). Gardner et al. (2010) recently highlighted the difficulty of differentiating between the ilia of caudates and anurans in Cretaceous microvertebrate deposits, and these problems are only exacerbated in Triassicage deposits when, presumably, the morphological divergence between the two taxa was less and there are other lineages of amphibians such as temnospondyls present to further confuse the question. The illustrated specimen does show a dorsally deflected acetabulum (Fig. 3.10a), but is admittedly incomplete and problematic. However, it is unlike the ilia of metoposaurs, as it is longer than wide rather than relatively tall and antero-posteriorly short (e.g., Sawin, 1945).

Thus there are potentially two taxa (a frog line batrachian and an indeterminate dissorophid), or a single, frog-line batrachian that retains the primitive atlanteal state at Moncure, although the latter hypothesis assumes that the tuberculum interglenoideum was not independently derived in Gerobatrachus and caudates. Regardless of whether they are caudate or salientian bones, the presence of these ilia, along with the double-faceted atlas, suggests the presence of at least one batrachian (or stem batrachian) in the Moncure deposit. Sues and Olsen (1990) described a possible lissamphibian jaw fragment from the similarly aged Tomahawk locality (although Milner, 1994 disputed the assignment). Any Triassic batrachian would be among the oldest lissamphibians from North America; however due to the fragmentary nature and the uncertainty of associating the salientian-like ilium with the caudate-like atlas, we urge caution in interpretation.

\author{
Class Amniota Linnaeus, 1758 \\ Amniota incertae sedis \\ Genus Colognathus (Case, 1928) \\ Species Colognathus obscurus (Case, 1928)
}

Figure 3.11, 3.12

We assign two bone fragments, each bearing an incomplete but highly distinctive tooth, to the enigmatic taxon Colognathus obscurus (Case). Both fragments exhibit acrodont tooth implantation, and the preserved teeth are relatively low and possess a striated, or fluted, enamel texture. The first specimen (NCSM 25186, Fig. 3.12) consists of a single conical tooth solidly affixed to a bone fragment. The tooth is pyramidal, essentially conical both in mesio-distal and labio-lingual views. The slope formed by the mesial surfaces is gentler than that of the distal surface, and the distal surface has a prominent bulge near the base. The base of the tooth is constricted on one side (lingual) and flush with the bone on the other. The tip is blunted and slightly worn such that the very apex of the tooth is slightly concave. These are diagnostic characteristics of the anterior teeth of Colognathus (Case, 1928; Murry, 1986; Heckert, 2004, 2006).

The second tooth, NCSM 25165, is particularly fragmentary but appears elongate and molariform (Fig. 3.11). The remnants of an elongate occlusal surface with a distinctive wear pattern and a slight invagination of the labial side are among the few preserved features, characteristics unique to Colognathus among Triassic tetrapods (illustrated by Heckert, 2004, figs. 64-65). Thus, we tentatively assign this tooth and the anterior tooth to Colognathus obscurus (Case). First described by Case (1928, 1933) as a fish, more recent authors have generally held it to represent a procolophonid (e.g., Murry, 1986; Sues and Olsen, 1993; Heckert, 2004). The taxon is under study by one of us $(\mathrm{ABH})$ and likely represents an archosauromorph, but a detailed revision is beyond the scope of this paper. Instead we note that these teeth clearly do not pertain to a rhynchosaur (Langer et al., 2000), a cynodont, or a procolophonid. The most similar taxon known from the Newark Supergroup is probably Gomphosauridion baileyae Sues and Olsen (1993), which also possesses fluted enamel but differs from Colognathus in having distinctly bicuspid teeth that are transversely broadened rather than elongate (Sues and Olsen, 1993). Teraterpeton hrynewichorum Sues (2003) has maxillary and dentary teeth that are transversely broadened but appear grossly similar in occlusal view, are oriented transversely, but are worn more unevenly (with upper teeth strongly worn mesially, lower teeth strongly worn distally). Sues (2003) makes no mention of fluted enamel. The teeth we describe here are also distinct from the prolacertiform Langobardisaurus from Late Triassic age strata of Italy in lacking a concave occlusal surface (Renesto and Dalla Vecchia, 2000). These two fragments are similar in size and could represent a single individual. This is the first record of Colognathus outside of the Chinle basin in the American Southwest.

\section{Amniota incertae sedis} Figure 4.6

The Moncure locality preserves many isolated, triangular teeth, which lack serrations or carinae, are unattached to any jaws, and also lack the acrodin caps that are diagnostic of actinopterygians (Janvier, 1996). These Moncure teeth, therefore, do not have affinity with dipnoans, coelacanths or chondrichthyans.Furthermore they are neither labyrinthodont like temnospondyls, nor polycuspate like the postcanines of 


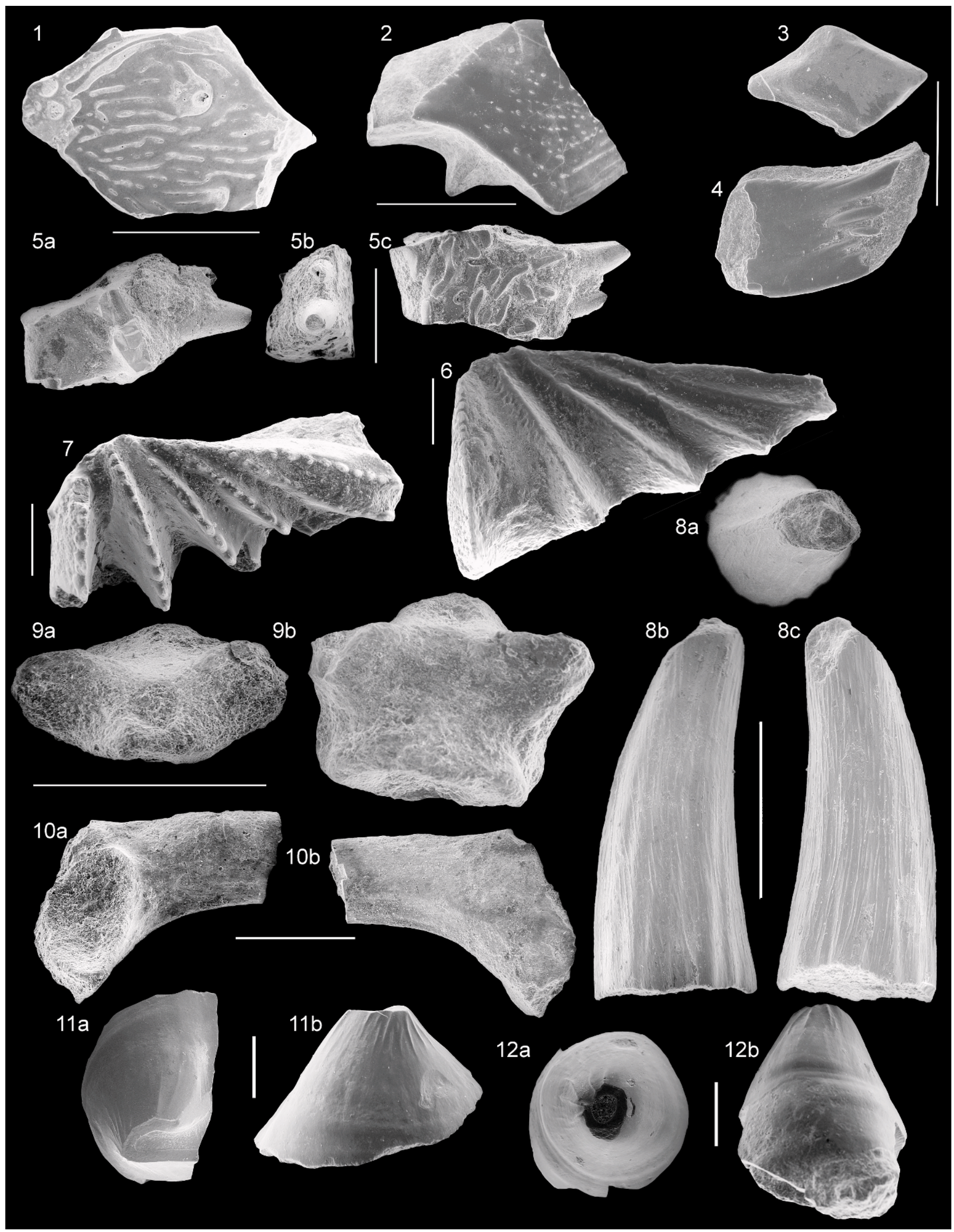


TABLE 2-Intercrest angles of lungfish teeth from the Moncure microvertebrate locality.

\begin{tabular}{|c|c|c|c|c|c|c|c|c|}
\hline Specimen & $\mathrm{ABC}$ & $\mathrm{C} 1 \mathrm{CP}$ & $\mathrm{C} 2 \mathrm{CP}$ & $\mathrm{C} 3 \mathrm{CP}$ & C4CP & $\mathrm{C} 5 \mathrm{CP}$ & C6CP & Position \\
\hline NCSM 23537 & 112 & 92 & 63 & 43 & 26 & 15 & 12 & \\
\hline NCSM 20764 & $\mathrm{X}$ & $\mathrm{x}$ & $83 ?$ & $53 ?$ & $34 ?$ & $21 ?$ & $15 ?$ & Pterygoid? \\
\hline NCSM 24720 & 102 & 88 & 62 & 42 & 31.5 & 13 & $\mathrm{x}$ & Pterygoid? \\
\hline NCSM 24719 & $\mathrm{X}$ & $66 ?$ & $57 ?$ & $43 ?$ & $30 ?$ & 11 ? & $\mathrm{x}$ & \\
\hline NCSM 20743 & 113.5 & 83 & 57 & 37 & 22 & $\mathrm{x}$ & $\mathrm{x}$ & Splenial? \\
\hline NCSM 20744 & $\mathrm{X}$ & $\mathrm{X}$ & $\mathrm{X}$ & $\mathrm{x}$ & $18 ?$ & $\mathrm{x}$ & $\mathrm{x}$ & $\mathrm{x}$ \\
\hline Averages & 109 & 88 & 61 & 40 & 26.5 & 14 & & \\
\hline
\end{tabular}

$\mathrm{x}$ specimen too damaged or incomplete to allow accurate measurement.

cynodonts, but do bear a strong resemblance to the teeth of sphenodontians, archosauromorphs and lepidosauromorphs. We assign these various teeth to Amniota incertae sedis, though a full description of these mostly isolated and nondiagnostic teeth is beyond the scope of this paper. One notable fossil is an acrodont dentary fragment with nutrient foramina, a Meckelian groove, and bulbous, low-crowned teeth (NCSM 25187, Fig. 4.6). The three preserved teeth are broken but were closely spaced and ovoid in cross-section. It strongly resembles the lower jaw and dentition of Uromastyx (Cooper and Poole, 2009, fig. 2c), although its phylogenetic position is unclear. It may represent a procolophonid or a lepidosauromorph.

Subclass DIAPSIDA Osborn, 1903

Infraclass LEPIDOSAUROMORPHA Benton, 1985

Lepidosauromorpha incertae sedis

Figure 4.1-4.4

Several jaw fragments bearing either pleurodont (Fig. 4.24.5) or acrodont (Fig. 4.5) dentitions have been recovered from the site. The acrodont fragments broadly resemble those of sphenodontians in having low, conical crowns, although the Moncure specimens lack the prominent vertical striations on the tooth crowns that are common in many primitive sphenodontians (reviewed by Jones, 2008; Evans and Jones, 2010). The pleurodont jaw fragments typically preserve several tall, simple, conical, somewhat laterally compressed teeth. Taken together, we consider the acrodont and pleurodont teeth to represent strong evidence of the presence of lepidosaurs, although we cannot rule out other more basal lepidosauromorphs with similar tooth implantation.

Lepidosauromorph jaw fragments are readily identifiable by their simple pleurodont implantation, subdued lingual shelf, and by a groove along the tooth bases (Rieppel, 1994). There are several different morphotypes from the Moncure locality, probably pertaining to multiple taxa, but given that any individual jaw type may also belong multiple taxa (or several may represent different variants of a single taxon), we refer to them only as morphotypes. The most complete lepidosauromorph specimen is NCSM 25177, an elongate left dentary fragment bearing all or parts of seven tooth positions, with broken roots in positions 1-2 but partial crowns present in the others (Fig. 4.1). We interpret this as a left dentary fragment based on the presence of the Meckelian groove near the ventral margin of the preserved bone. The teeth are poorly preserved, but subcylindrical with striations basally. None are complete but the low crowns in positions 4-5 suggest that they were probably relatively low. The bone is proportionately elongate, low and flat, and much broader posteriorly than anteriorly. However, anteriorly the teeth are very near the lateral margin of the bone, with much bone lingual to the dentition, this condition is reversed posteriorly. There is a single, proportionately large nutrient foramen on the lateral surface underneath teeth $3-4$, and there may be the remnants of another at the anterior edge.

A pleurodont jaw fragment, NCSM 25178 (Fig. 4.2) bears four teeth flanked by broken tooth positions. The teeth are situated on a prominent shelf. We tentatively interpret this as a left maxilla based on the nutrient foramina, the absence of a Meckelian groove, and a somewhat posteriorly directed third tooth. The labial surface is relatively deep, even though broken dorsally, and has a very fine texture of pits and grooves. All of the teeth are broken, but remnants are all relatively low, conical, and circular in cross-section. Three potential replacement teeth are evident; two on either side of the first tooth, including one anterior to the cavity (resorbed base) of the second tooth, and another between the third and fourth teeth.

Among the tooth-bearing fragments with pleurodont implantation is NCSM 24741 (Fig. 4.3), which preserves three tooth positions, with an incomplete tooth in the first and a broken tooth in the third. We interpret this specimen as part of the rostral portion of the left dentary, but cannot rule out the right premaxilla. A string of at least five nutrient foramina are evident on the lateral margin, with one anterior to the more complete tooth and two each associated with the first tooth and the first vacant position. A pleurodont dentition near the rostral tip of the mandible is a feature common in squamates but also seen in basal sphenodontians (Fraser and Shelton, 1988). The more complete crown is moderately low, blunt, and circular in cross-section with faint striae evident on the labial side (Fig. 4.3c). The second position is empty and deep, but not socketed - if there is bone between tooth positions it is very thin and low. In occlusal view the crown of the broken third tooth is ovoid, with the long axis transversely oriented in the jaw. The enamel is relatively thick. The tooth core is hollow, with $\sim 40 \%$ of the dentine thickness missing. The

$\leftarrow$

FIGURE 3-Scanning electron micrographs of osteichthyans and lower tetrapods from the Moncure microvertebrate locality, Cumnock Formation, North Carolina. 1-4, typical fish scales (NCSM 25696-25699) found at the Moncure locality, showing a wide range of variation in terms of shape and ornamentation; 5, NCSM 24735, a typical dentulous fish cranial element, showing the enameloid knobs and subpleurodont tooth implantation in lingual (a), occlusal (b) and labial (c) views, with apical to the right; 6, Arganodus sp. worn dental plate (NCSM 20742) in occlusal view; 7, Arganodus sp. unworn dental plate (NCSM 20743) in occlusal view; 8, labyrinthodont tooth of a stereospondyl, possibly a metoposaur, (NCSM 23566) in occlusal (a), lingual $(b)$, and labial views (c); 9, possible batrachian atlas (NCSM 25232) in cranial (a) and dorsal (b) views; 10, possible batrachian ilium (NCSM 25164) in lateral $(a)$ and medial (b) views; 11, 12, Colognathus obscurus (Case, 1928) bone fragments with teeth: 11, molariform tooth fragment (NCSM 25165) in occlusal $(a)$ and distal $(b)$ views; 12, anterior tooth (NCSM 25186) in occlusal $(a)$ and mesial? (b) views. All scale bars 1 mm. 


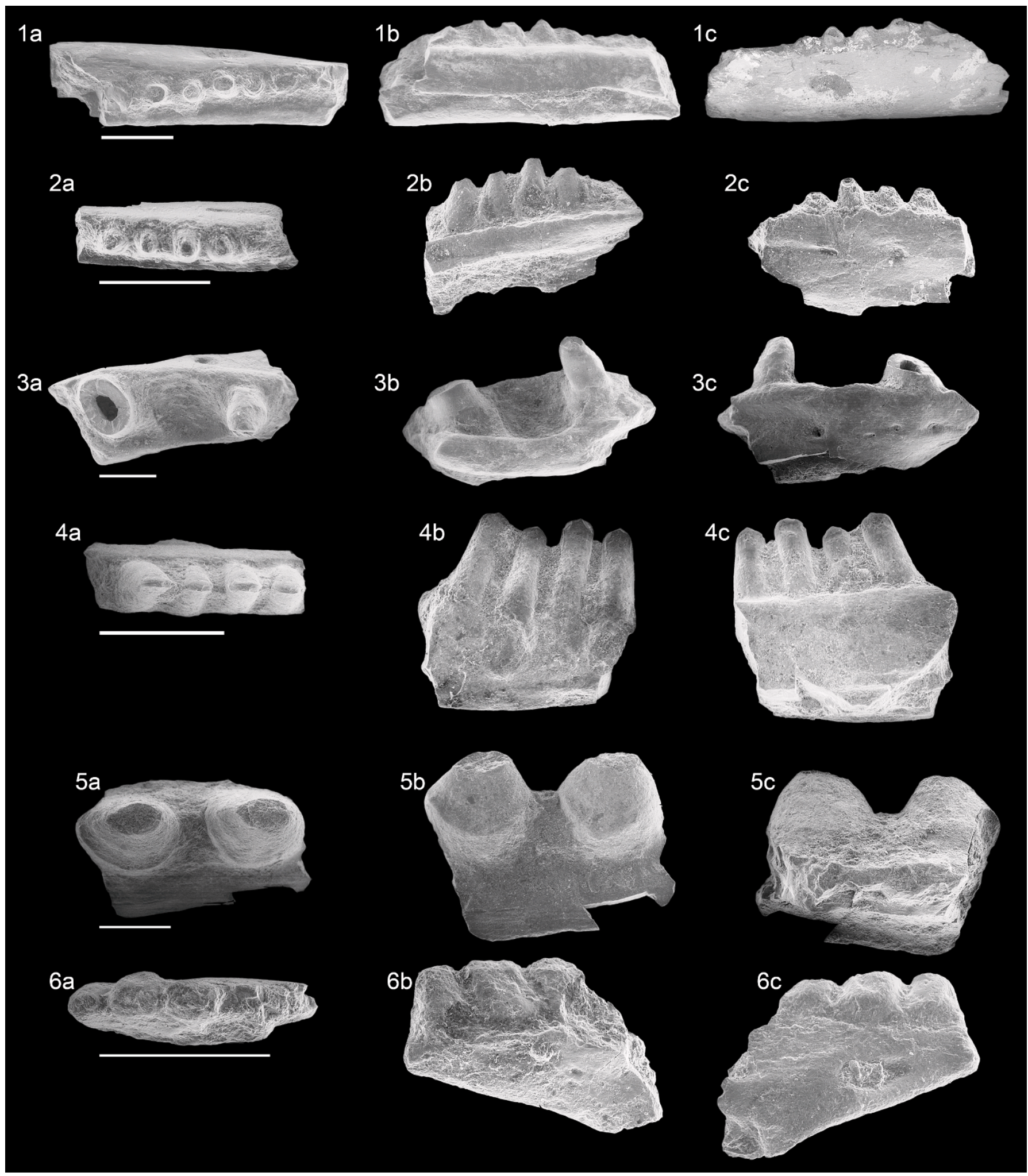

FIGURE 4-Scanning electron micrographs of lepidosauromorphs (1-4), a sphenodont (5) and an indeterminate amniote (6) from the Moncure locality, Cumnock Formation, North Carolina, all in occlusal $(a)$, lingual $(b)$ and labial $(c)$ views. 1, pleurodont left dentary fragment (NCSM 25177); 2, pleurodont left maxillary fragment (NCSM 25178); 3, left? dentary fragment (NCSM 24741); 4, pleurodont jaw fragment (NCSM 24733); 5, sphenodontian jaw fragment (NCSM 24734); 6, acrodont right dentary fragment (NCSM 25187). All scale bars $1 \mathrm{~mm}$.

surface opposite the dentition is broken but appears to have had thin sheets of bone projecting dorsally.

Another bone fragment bearing teeth with pleurodont implantation is NCSM 24733, which preserves much of four consecutive tooth positions (Fig. 4.4). Total tooth height, even in labial view, is only twice tooth length. The remnants of a Meckelian groove are low on the preserved portion (Fig. 4.4b). The bone is broken basally so was probably 
thicker. In labial view (Fig. 4.4c) the teeth appear to be ankylosed basally and lingually. The preserved crowns have faint longitudinal striations, especially on the posterior surface of the specimen. The tooth crowns are strongly compressed and appear chisel-tipped, although the teeth are chipped apically.

Superorder LEPIDOSAURIA Haeckel, 1866

Order SPHENODONTIA Williston, 1925

Family SPHENODONTIDAE Cope, 1869

Figure 4.5

An acrodont jaw fragment bearing two teeth, NCSM 24734 (Fig. 4.5) appears to represent a sphenodontian. Matrix between the two teeth makes them appear shorter than they really are-very little of the preserved specimen is bone. We illustrate the specimen as if it is a right lower jaw but its actual position is impossible to ascertain. Both teeth are conical, with slightly elongated mesio-distal axes. The apices of both are chipped, and in the anterior tooth this resembles a wear facet, although preservation of the enamel is poor. Similarly, both teeth appear to possess a slight bulge near the base of the lingual surface, resembling an incipient cingulum, although this is likely a taphonomic artifact. The jaw fragment is broken but neither root penetrates this outer layer of bone, so it is clear that the teeth are acrodont and not thecodont (Fig. 4.5c). Although acrodont implantation occurs within several lineages, including sphenodontians, various lizards (Agamidae, Chamaeleonidae, and some members of Anolis), and superficially acrodont dentitions are evident in some procolophonids and even some fish, we reject those possible identifications, based on the swollen crowns and apical wear facets in the Moncure material. These are consistent with the condition found in sphenodontians, especially taxa slightly more derived than the most basal forms (Fraser and Shelton, 1988; Heckert, 2004; Datta and Ray, 2006).

Infraclass ARCHOSAUROMORPHA Huene, 1946

Unranked clade ARCHOSAURIFORMES Gauthier, 1984 sensu Gauthier et al., 1988

Archosauriformes incertae sedis

Archosauriformes refers to a number of taxa more derived than the basal archosauromorphs but includes several lineages outside of crown-group Archosauria; it was named by Gauthier (1984) but not formally published before Gauthier et al. (1988). Godefroit and Cuny (1997; see also Heckert, 2004) built upon existing phylogenies of archosauromorphs and basal archosaurs to identify the following synapomorphies of archosauriform teeth: thecodont implantation and conical to recurved crown with anterior and distal carinae that may be serrated or otherwise modified by denticles. Subsequent phylogenies (e.g., Nesbitt, 2011) have not substantially modified these criteria, so we use these characteristics to identify a variety of teeth as archosauriform, acknowledging that some may in fact represent crown-group archosaurs (described in the following section).

Some archosauriform morphotypes are not easily assigned to a less inclusive group. Representative morphotypes are briefly described and illustrated here (e.g., Fig. 5.4-5.7). Most are moderately tall (TCH $\sim 2.5 \mathrm{TCL}$, following Heckert, 2004) and range in shape from conical (NCSM 24739, Fig. 5.5) through weakly recurved (NCSM 25157, Fig. 5.4) to strongly recurved (NCSM 25156, Fig. 5.7). Most are laterally compressed. Denticles are typically fine $(\sim 8-12 \mathrm{~mm})$ and perpendicular to the tooth margins, forming typical archosauriform serrations. Usually, both carinae are serrated but sometimes the mesial carina is only weakly or incompletely serrated (e.g., NCSM 24156, Fig. 5.7). Both Godefroit and Cuny (1997) and Heckert (2004) attempted to encapsulate microvertebrate archosauriform diversity in part by assigning taxa to morphotypes. The teeth illustrated here are broadly similar to Heckert's morphotypes but tend to have coarser denticles and may generally be slightly larger. In particular, NCSM 24739 (Fig. 5.5) matches Heckert's (2004) morphotype $\mathrm{Q}$ in that it is moderately low (TCH $\sim 1.5-2 \mathrm{TCL})$, conical, laterally compressed, and has mesial and distal serration that are coarser basally and finer apically. Heckert's (2004) morphotype $\mathrm{S}$, which is tall, conical, laterally compressed to tear-shaped in occlusal view and bearing coarse denticles posteriorly is best represented by NCSM 25156 (Fig. 5.7). Moderately low, conical to weakly recurved, laterally compressed teeth exemplified by NCSM 25158 (Fig. 5.6) bear a strong resemblance to the posterior teeth of Dromicosuchus grallator Sues et al. (2003) but could also be a phytosaur blade tooth, albeit a strongly laterally compressed one.

Although some of the archosauriform morphotypes probably represent juvenile phytosaurs, "rauisuchians" sensu lato, or other crown-group archosaurs, others have no apparent match and, like the morphotypes documented from the Rhaetian of Saint-Nicolas-de-Port (Godefroit and Cuny, 1997) and throughout the lower Chinle Group (Heckert, 2004), hint at a greater diversity of small-bodied archosauriforms than is presently known from skeletal material. There are literally several hundred such teeth and tooth fragments, so it is unclear how many taxa or individuals are represented in the assemblage.

\section{cf. Genus Galtonia Hunt and Lucas, 1994 cf. Species Galtonia GibBidens (Cope, 1878)}

Figures 5.3, 5.9

Among the archosauriform tooth morphotypes is a form with relatively low tooth crowns with coarse denticles that are subperpendicular to the tooth margin (NCSM 23538, Fig. 5.3). This gross morphology is similar to the archosauriform Galtonia gibbidens from the New Oxford Formation in Pennsylvania, originally considered a prosauropod (Cope, 1878; Huene, 1921) and, later, an ornithischian (Hunt and Lucas, 1994) dinosaur. Irmis et al. (2007; see also Nesbitt et al., 2007) considered Galtonia gibbidens indistinguishable from Revueltosaurus. However, Galtonia teeth are generally more laterally compressed and have proportionately larger denticles than does Revueltosaurus. We identify some teeth with these characteristics from Moncure as cf. Galtonia gibbidens in that they are only slightly asymmetrical in occlusal view, with welldeveloped carinae with prominent denticles that are subperpendicular to the tooth margin (Hunt and Lucas, 1994, fig. 12.4a-f). The Moncure specimens are smaller and more laterally compressed than those described by Hunt and Lucas (1994) hence our somewhat tentative identification. Another illustrated specimen (NCSM 24730, Fig. 5.9), while broken, is less worn than the type series of Galtonia gibbidens, so the denticles appear more sharp and prominent. Because these teeth are more laterally compressed, they resemble the teeth of basal sauropodomorphs (including many "prosauropods"). However, recent discoveries have demonstrated that dentitions superficially similar to those of herbivorous dinosaurs (e.g., "prosauropods" and basal ornithischians) are much more widespread phylogenetically, being present in Azendohsaurus, silesaurids and revueltosaurs, among other taxa (Dzik, 2003; Parker et al., 2005; Irmis et al., 2007; Flynn et al., 2010). Thus, the teeth of Galtonia may pertain to a silesaurid or other taxon within crown-group archosaurs. 


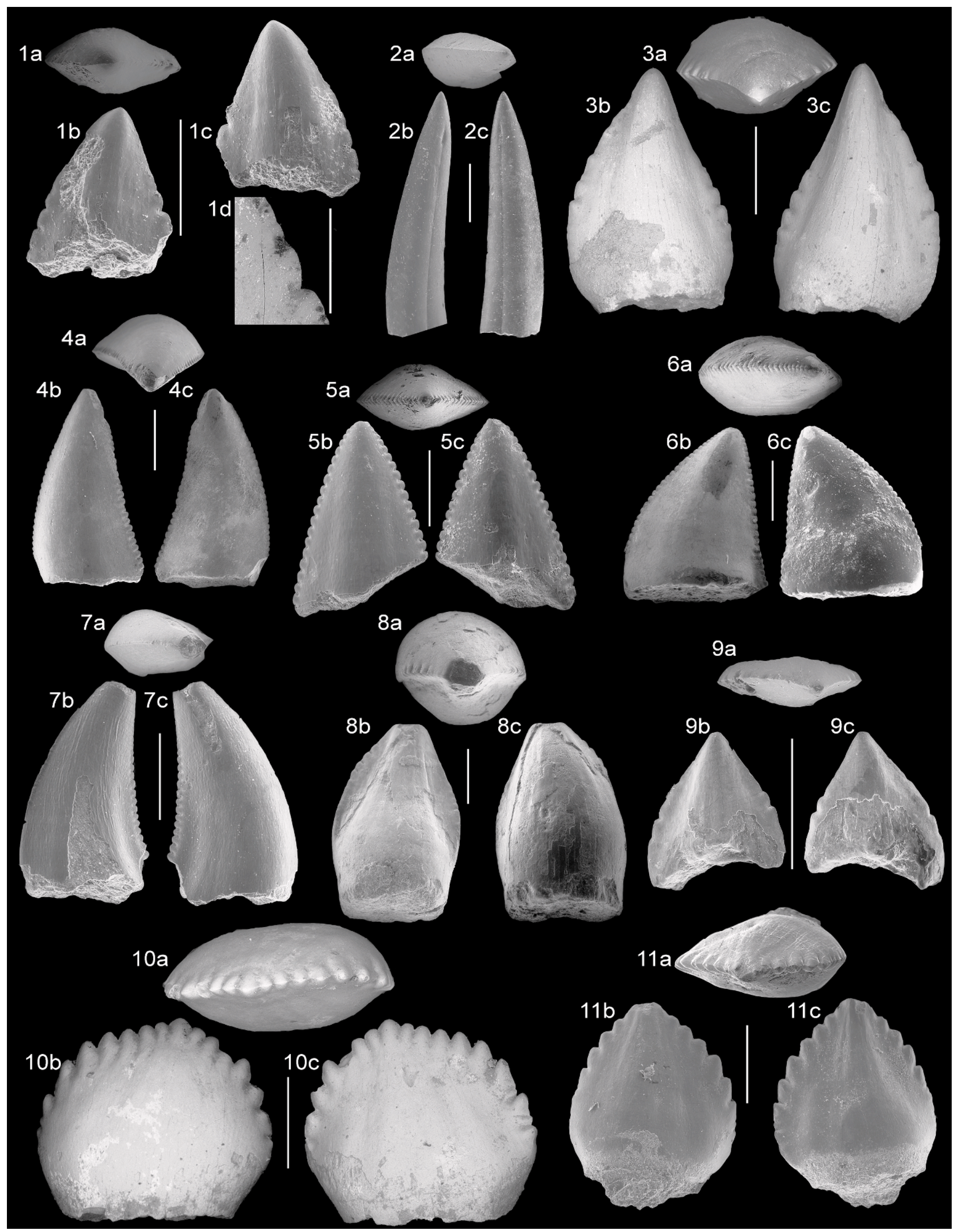


The tooth illustrated here (NCSM 23538, Fig. 5.3) is typical of cf. Galtonia gibbidens teeth from Moncure. The crown is moderately tall, conical, somewhat laterally compressed, and possesses denticles that are strongly offset from the tooth margin. The denticles are coarser basally and finer (and worn) apically, preventing an accurate count, but there are typically 6 to 7 well-developed denticles basal to the smoother apical surfaces. The denticles themselves are conical and strongly pointed. These teeth are more laterally compressed than those we assign to Revueltosaurus and are not as worn, with most still preserving intact denticles, especially basally. They also differ from typical Revueltosaurus crowns in being more symmetrical in side view (more conical, less recurved) and possessing denticles that coarsen all the way to the basal-most denticle, which is always the largest. Sometimes, as in NCSM 24730 (Fig. 5.9) there is a persistent bulge on the labial side that is clearly distinct from the more laterally compressed carinae.

The teeth we describe and illustrate here from Moncure are quite similar to those of Azendohsaurus, most recently reviewed by Flynn et al. (2010). Points of detailed similarity include the conical to weakly recurved shape, expanded base, lateral compression, and offset denticles (compare to Flynn et al., 2010, text-fig. 12). The Moncure specimens possess fewer, proportionately coarser denticles. Interestingly, most of these teeth are relatively low, and would therefore appear to represent the upper (including palatal-palatine and ectopterygoid) dentition of an Azendohsaurus-like taxon. Because the teeth bear resorbtion pits, they were shed, which makes it impossible to confirm whether or not they were ankylosed to the jaw (ankylothecodont implantation) as is typical of Azendohsaurus (Flynn et al., 2010).

These teeth are also similar to those of some silesaurids sensu Nesbitt et al. (2010). They differ from Silesaurus and Asilisaurus in that they have fewer, more prominent denticles and lack the strong longitudinal ridges exemplified by Silesaurus (Dzik, 2003). They are much more laterally compressed than, and lack the cingulum of Sacisaurus (Ferigolo and Langer, 2007), which appears to have similarly coarse denticles. Their shape is similar to the newly discovered taxon Diodorus scytobrachion Kammerer et al. (2011), which also lacks the cingulum. Unlike Diodorus, the denticles on the teeth we describe here coarsen basally, which appears to be opposite the pattern illustrated by Kammerer et al. (2011, fig. 1). Thus far we have only identified a few of these teeth $(\sim 10)$ from the fauna.

\section{Genus Crosbysaurus Heckert, 2004 CROSBYSAURUS sp. Figure 5.1}

Heckert (2004) diagnosed Crosbysaurus by the presence of a low crown with an expanded distal carina and proportionately coarse, compound denticles, particularly on the distal (posterior) margin. Two morphotypes were assigned to this genus. These are hypothesized to represent a distinct anterior and posterior dentition, with the more anterior (premaxillary?) teeth taller and weakly recurved, while the posterior teeth are shorter, with a relatively longer distal carina and less curvature. This variation is reasonable within the bounds of archosaur heterodonty, the more 'posterior' dental form was chosen for the holotype, and the tooth we describe here (NCSM 25166, Fig. 5.1) is similar in size and shape to posterior Crosbysaurus teeth, which themselves are relatively unusual in having a somewhat "fore-swept" shape (e.g., Heckert, 2004, figs. 51-53). This shape, combined with the presence of compound denticles, is unique to Crosbysaurus. This Moncure specimen illustrated here (Fig. 5.1), although somewhat worn, preserves the basal sub-denticled denticles that are offset (not perpendicular to the tooth margin) as described and illustrated by Heckert (2004). However, the denticles are not as extensively subdivided (e.g., Fig. 5.1d) as typically seen in Crosbysaurus so we only refer these teeth to Crosbysaurus sp.

In spite of its distinctive dentition, the affinities of Crosbysaurus remain enigmatic. It almost surely does not represent an ornithischian (Irmis et al., 2007), but could still represent one of many different basal archosaurs or archosauriforms, including pterosaurs, many of which have relatively complex denticles. The complex subdenticles of Crosbysaurus are generally distinct from the simply divided compound denticles of Uatchitodon (see below). Thus, even though both taxa are known from the Placerias quarry in Arizona (ABH, personal observation), we do not think that they represent the same taxon, as otherwise the two taxa do not co-occur through several localities in Texas, New Mexico, and Arizona for Crosbysaurus (Heckert, 2004) and Virginia, North Carolina, and Arizona for Uatchitodon (Mitchell et al., 2010). Only a single other tooth referable to Crosbysaurus sp. (NCSM 25167) was recovered at Moncure.

\section{Genus Uatchitodon Sues, 1991 \\ Species UAtChitodon SCHNEIDERI Mitchell et al., 2010} Figure 5.2

One of the most distinctive archosauriform taxa known from Moncure is the venomous Uatchitodon schneideri Mitchell, Heckert, and Sues (2010), the holotype of which (NCSM 24753, Fig. 5.2) is illustrated here. Approximately 60 teeth and tooth fragments preserve features consistent with Uatchitodon (Mitchell et al., 2010). The most complete teeth are conical to weakly recurved, laterally compressed, with thecodont implantation and serrated carinae, consistent with an assignment to Archosauriformes. Further, they are proportionally tall (crown height is up to five times basal length) and bear subdivided serrations ( compound denticles), two apomorphies of Uatchitodon. The third apomorphy of Uatchitodon is a longitudinal (baso-apical) canal on both the lingual and labial surfaces that is open along most of the crown in Uatchitodon kroehleri but enclosed in the Moncure form, Uatchitodon schneideri (Sues, 1991; Sues et al., 1994; Mitchell et al., 2010). Despite closure of the canals, there is

$\leftarrow$

FIGURE 5-Scanning electron micrographs of archosauriform teeth from the Moncure locality, Cumnock Formation, North Carolina, all in occlusal (a), labial $(b)$ and lingual $(c)$ views unless otherwise noted. 1, Crosbysaurus sp. tooth (NSCM 25166) in occlusal $(a)$, labial $(b)$, lingual $(c)$, and close-up of basal distal denticles $(d)$ views; 2, Uatchitodon schneideri Mitchell, Heckert, and Sues (2010) holotype premaxillary(?) tooth (NCSM 24753); 3, cf. Galtonia gibbidens. (NCSM 23538); 4-6, archosauriform incertae sedis teeth (NCSM 25157, 24739, and 25158, respectively); 7, common morphotype of archosauriform incertae sedis tooth (NCSM 25156), possibly from a more posterior (distal) position in the same taxa as 4 , which appears to be a more anterior (mesial) tooth; 8, Revueltosaurus olseni (Hunt and Lucas, 1994) new combination, anterior (mesial) premaxillary tooth (NCSM 24727) showing worn carinae; 9, tooth of the Galtonia-like morphotype (NCSM 24730); 10, wide, low-crowned tooth of Revueltosaurus olseni with coarse, nearly vertical denticles (NCSM 23541); 11, posterior (distal) Revueltosaurus olseni maxillary/dentary tooth (NCSM 21650 ). All scale bars 1 mm except $1 d 400 \mu m$. 
often a slight furrow on the lateral surfaces of the crown, indicating the presence of a canal within the tooth, as seen in Figure 5.2. Occasionally there is no external sign of the canals, requiring a cross-section to confirm their presence. Uatchitodon schneideri is also known from the Placerias quarry in the lower Chinle Group of eastern Arizona (Kaye and Padian, 1994; Sues, 1996; Mitchell et al., 2010). Uatchitodon provides an interesting test case for exploring evolutionary hypotheses, as the earliest vertebrate with a fully enclosed canal system, and the only venomous vertebrate with a complete sequence of teeth from a shallow groove to a canal, a sequence explored elsewhere (Mitchell et al., 2010). It appears that all teeth of Uatchitodon possessed the venom tubes (see Mitchell et al., 2010 for rationale for tooth placement), so it is unclear how many individuals might be represented by the 60 or so teeth and tooth fragments we report here.

\section{Unranked clade ARCHOSAURIFORMES indet. "Rauisuchia" \\ Figure 2.14}

Fragmentary larger teeth recovered from the site attest to the presence of large archosauriforms, probably "rauisuchians" sensu lato. The preserved teeth (NCSM 19583, NCSM 20831, Fig. 2.14) are incomplete but obviously large ( $20 \mathrm{~mm}$ fore-aft basal length, probably $50 \mathrm{~mm}$ crown height). They are strongly laterally compressed, recurved, and bear fine (12 to 14 per $5 \mathrm{~mm}$ ) denticles on both the mesial and distal carinae, all characteristics of Archosauriformes sensu Godefroit and Cuny (1997) and Heckert (2004). These teeth are more strongly laterally compressed than most phytosaur teeth, and taller and more recurved than the posterior phytosaur teeth (type B teeth of Hunt, 1989b; maxillary teeth of Hungerbühler, 2000). They are much larger than those known from any contemporaneous theropod or other dinosauromorph. They resemble the teeth of large "rauisuchians" such as Postosuchus or Saurosuchus (Chatterjee, 1985; Long and Murry, 1995; Alcober, 2000) but could pertain to a more basal or more derived archosauriform, so we refer them to "Archosauriformes indet." here, recognizing that they probably pertain to a rauisuchian sensu Brusatte et al. (2010) but that a more basal affinity is possible. These teeth are also among the largest fossils recovered from the Moncure locality.

\section{Division ARChOSAURIA Cope, 1869 \\ Subdivision CRUROTARSI Sereno, 1991 \\ Family Phytosauridae Jaeger, 1828 Phytosauridae indet.}

Figure 5.4

Several taxa from the Moncure locality represent crown group archosaurs. Chief among these are a few larger tooth fragments ( 2 to $3 \mathrm{~cm}$ crown height) that represent various morphotypes commonly associated with phytosaurs (e.g., Hunt, 1989b; Hungerbühler, 2000). These include mesiodistally serrated, distally serrated, and unserrated teeth with baso-apical striations (ridges) ascribed to type B, I, and U teeth sensu (Hunt, 1989b) catalogued under numbers NCSM $23552,23553,23586,23587$, and 23588. In spite of the work of Hunt (1989b) and Hungerbühler (2000), taxonomic and, especially, ontogenetic variation in phytosaur dentitions remains poorly understood, and even positional variation has not been assessed quantitatively or with great rigor across taxa. Given the large number of tooth positions and expected high rate of tooth replacement, it is therefore likely that at least some archosauriform teeth described here probably pertain to phytosaurs. Examples include NCSM 25157 (Fig. 5.4) and NCSM 25158 (Fig. 5.6), although the latter tooth is homoplastic enough that it could pertain to a wider array of archosauriforms as discovered previously. Larger phytosaur fossils are also commonly recovered from other localities at this quarry, including an as-yet-unprepared skull (NCSM 19078) found $3 \mathrm{~m}$ stratigraphically lower than the locality documented here.

One recent analysis has removed the phytosaurs from crown group Archosauria (Nesbitt, 2011), but they are listed as archosaurs here pending further analysis, acknowledging that the group is monophyletic and either just inside the crown group (as basal "pseudosuchians" in most analyses) or just outside of it (Nesbitt, 2011). Because of the wide range within phytosaur dentitions, it possible that many of the hundreds of archosauriform teeth recovered from the Moncure site represent phytosaurs, and at least one large and one small, presumably juvenile individual are represented by the teeth we document here.

\section{Subdivision CRUROTARSI Sereno, 1991 OR SUCHIA, Krebs 1974 sensu Nesbitt, 2011 Genus Revueltosaurus Hunt, 1989a}

Diagnosis.-Modified from Heckert (2002). Moderately large, primitive archosauriform distinguished by a combination of its size (tooth crowns approximately 7 to $15 \mathrm{~mm}$ tall); numerous small denticles (more than 7 per carina) that are offset (subperpendicular) to the tooth margin; denticles proportionately short and often worn to the enamel by precise occlusion; Revueltosaurus also lacks a true cingulum that was involved in mastication; premaxillary tooth crowns are approximately twice as tall as maxillary/dentary tooth crowns and weakly recurved; maxillary/dentary tooth crowns phyllodont (leaf-shaped). We note that the emended diagnosis in Parker et al. (2005) was exclusive of the teeth which they considered adequately diagnosed by Heckert (2002).

\section{Species Revueltosaurus OlSENI (Hunt and Lucas, 1994)} Figure 5.8, 5.11

Pekinosaurus olseni Huber, LuCAS AND Hunt, 1993, p. 176, Fig. 3c, 3d.

Pekinosaurus olseni HUNT AND LUCAs, 1994, p. 231, fig. $12.4 \mathrm{~g}-\mathrm{j}, 12.5 \mathrm{a}-\mathrm{f}, 12.8 \mathrm{~b}, 12.8 \mathrm{~d}$; IRMIS, PARKER, NESBITT AND LiU, 2007, p. 6, fig. 4d, tab. 1; Pekinosaurus olseni: NesBitT, IRMIS AND PARKER, 2007, p. 230, fig. 8k1. See discussion.

Type series.-Holotype: YPM 7666, an isolated maxillary/ dentary tooth (not YPM 8545, see discussion). Specimens referred by Hunt and Lucas (1994) are YPM 7667, maxillary/ dentary tooth and YPM 7668-7669, premaxillary teeth.

Type locality and horizon.-Putatively the Pekin Formation, Montgomery County, North Carolina (see discussion); the Moncure locality is in the Cumnock Formation.

Referred specimens.-All are NCSM specimens from Moncure, 21647, premaxillary tooth; 21650, maxillary/dentary tooth (Fig. 5.11); 21651-21652, maxillary/dentary tooth; 23539, worn premaxillary tooth; 23541, maxillary/dentary tooth (Fig. 5.10); 23542, premaxillary tooth; 23543-44, maxillary/dentary teeth; 23545, premaxillary tooth; 23546, maxillary-dentary tooth; 23548, maxillary/dentary tooth; 23549, premaxillary tooth; 23550, maxillary/dentary tooth; 235552-23557, maxillary/dentary teeth; 24727, premaxillary tooth (Fig. 5.8); 24758, premaxillary tooth; 24759, maxillary/ dentary tooth fragment; 24760, maxillary/dentary tooth; 24761-2, premaxillary teeth; 25194-25227, teeth and tooth 
fragments, including premaxillary teeth (25185-25205, 25213, $25217,25219,25221,25226-25227)$ and maxillary/dentary teeth $(25194,25206-25211,25215-216,25218,25220,25220-$ 225, 25229). Similar teeth that are assigned to Revueltosaurus? include NCSM 24728, maxillary/dentary tooth, 25192 and 25228, enamel-less (digested?) maxillary/dentary teeth; 25193, tooth embedded in matrix.

Distribution.—Late Triassic age Cumnock Formation, Deep River Basin, North Carolina.

Diagnosis.-Species of Revueltosaurus characterized by maxillary-dentary teeth that can be longer than tall (TCL

$\mathrm{TCH}$ ), even when unworn, and therefore with vertically oriented apical denticles; teeth of $R$. olseni generally lack the precise wear of the denticles often seen in $R$. callenderi.

Description.-Premaxillary teeth of Revueltosaurus olseni are extremely similar to the holotype and referred specimens of $R$. callenderi in that they are phyllodont (leaf-shaped to slightly recurved, slightly taller than long (TCH $\sim 1.25$ $2 \mathrm{TCH}$ ) with pronounced carinae that each bear $7+$ denticles that are offset (subperpendicular) relative to the tooth margin, and that coarsen basally. Some but not all, have a few more basal denticles that are finer. Maxillary/dentary teeth are proportionately more symmetrical in labio-lingual view, and are proportionately broader and lower, with TCL typically $\mathrm{TCH}$, with well-developed denticles that are nearly vertical.

Discussion.-The Moncure locality yields many teeth that are similar to, but distinct from, the crurotarsan archosaur Revueltosaurus callenderi Hunt (1989a). Originally known only from teeth and thought to represent an ornithischian dinosaur (Hunt, 1989a; Hunt and Lucas, 1994; Heckert, 2002), more complete skull and postcrania demonstrated that Revueltosaurus is actually a crurotarsan, but that the type specimens are still diagnostic (Parker et al., 2005). We assign several teeth to Revueltosaurus based on the presence of seven or more coarse, slightly offset (non-perpendicular) denticles on each side of tooth crowns that are relatively low (crown height less than twice crown length) and asymmetrical in occlusal view (Heckert, 2002, 2005). The teeth recovered from the Moncure locality (e.g., NCSM 21650, Fig. 5.11) thus resemble $R$. callenderi but lack the precise wear on the denticles and fine basal denticles that typify maxillarydentary teeth of this species. They are also similar to the type and referred specimens of the putative ornithischian Pekinosaurus olseni Hunt and Lucas (1994, fig. 12.5a-f) so we refer them to Revueltosaurus olseni here, acknowledging that Pekinosaurus is a junior synonym of Revueltosaurus as hypothesized by Irmis et al. (2007) and Nesbitt et al. (2007). Particularly important is the preservation of maxillary/dentary teeth that are wider than tall with numerous denticles that are subvertical. In the Moncure sample this is best seen in NCSM 23541 (Fig. 5.10). We note that exceptionally wide teeth such as this result in denticles that are oriented essentially vertically, something that is characteristic of the holotype and referred maxillary/dentary tooth of Revuletosaurus olseni as well (Hunt and Lucas, 1994, fig. 12.5a-c). Teeth such as NCSM 23541 (Fig. 5.10) are similar to the "ornithischian type 3" tooth from Saint-Nicolas-dePort illustrated by Godefroit and Cuny (1997, pl. 11-m; considered Archosauriformes incertae sedis by Irmis et al., 2007), but are more bulbous and asymmetrical in occlusal view. There are a few small fragments of osteoderms that resemble those of Revueltosaurus (Parker et al., 2005) but are too incomplete to be diagnostic. One such example, NCSM 23290 (Fig. 2.16) is illustrated here. This osteoderm is incomplete but rectangular with ornament consisting of a random array of shallow subcircular pits, characteristics typical of Revueltosaurus (Parker et al., 2005) but paralleled in some aetosaurs (e.g., Heckert and Lucas, 2000; Parker, 2007).

There is some confusion in the literature regarding the type series of Revueltosaurus ( Pekinosaurus) olseni. Although numerous authors have commented on the taxonomic status of Pekinosaurus and Galtonia, no new illustrations have been produced since Hunt and Lucas (1994), as those in subsequent publications (e.g., Heckert and Lucas, 1997; Irmis et al., 2007; Nesbitt et al., 2007) are apparently redrawn from Hunt and Lucas (1994). Huber et al. (1993a), anticipating publication of Hunt and Lucas (1994), referred to the holotype as YPM 8545, the designation used by Hunt et al. (1994) when the name was established. Hunt and Lucas (1994) considered a maxillary/ dentary tooth with this number the holotype and referred three other teeth (one maxillary/dentary, and two premaxillary) with the same number. Although Parker et al. (2005) determined that Revueltosaurus was not an ornithischian but instead a crurotarsan, they also confirmed earlier parties' hypotheses that Revueltosaurus teeth are diagnostic to at least the generic level. Irmis et al. (2007; see also Nesbitt et al., 2007) expanded upon Parker et al. (2005) to consider Pekinosaurus olseni Hunt and Lucas and Galtonia gibbidens (Cope, 1878) indistinguishable from Revueltosaurus sp. (Irmis et al., 2007, p. 6, table 1 on p. 17; Nesbitt et al., 2007) or "related forms" (Irmis et al., 2007, p. 8). Irmis et al. (2007) correctly identified, without comment, the holotype as YPM 7666. Nesbitt et al. (2007) followed Hunt and Lucas (1994) in identifying the holotype as YPM 8545, although they considered the taxon to represent Revueltosaurus, following Irmis et al. (2007). Casts in our possession identify the holotype and referred specimens as YPM 7666-7669, and communication with collections personnel at YPM confirm that YPM 7666-7669 are indeed the appropriate numbers. Of these, YPM 7666 clearly matches the holotype illustrated by Hunt and Lucas (1994, fig. 12.4a-c), so we concur with Irmis et al. (2007) that this number represents the holotype. YPM 7667 is also a maxillary/dentary tooth, and is the referred maxillary/dentary tooth illustrated by Hunt and Lucas (1994, fig. 12.5a-c). YPM 7668-69 are both premaxillary teeth, and Hunt and Lucas (1994, fig. 12.5d-f) illustrated YPM 7668.

We also note here that fieldwork by one of us (PEO) has shown that strata formerly assigned to the Pekin Formation in Montgomery County, North Carolina, including the type locality of Pekinosaurus olseni, actually pertain to the overlying Cumnock Formation. Thus the type series of Pekinosaurus olseni is actually from approximately the same stratigraphic interval as the Moncure locality.

As the large number of referred specimens from the Moncure site shows, Revueltosaurus is one of the more common tetrapod taxa in the assemblage. Although this may in part be an artifact of their distinctiveness compare to other archosauriform teeth, many of the Revueltosaurus teeth are larger than the bulk of archosauriform teeth as well. Thus, Revueltosaurus appears to be common in this assemblage, especially given that the total number of tooth positions is relatively few in comparison to many Triassic archosaurs (Parker et al., 2005), particularly phytosaurs (e.g., Hungerbühler, 2000), so the sixty catalogued teeth and numerous tooth fragments likely represent several individuals. 


\author{
Class SYNAPSIDA Osborn, 1903 \\ Order THERAPSIDA Broom, 1905 \\ Division CYNODONTIA Owen, 1861 \\ Suborder EUCYNODONTIA Kemp, 1982 \\ Unranked clade GompHodonTIA Seeley, 1895, \\ sensu Hopson and Kitching, 2001 \\ Cynodontia indet. \\ Figure 6.1
}

The Moncure locality yields numerous cynodont fossils, many of which are incisors and canines that are not diagnostic below Cynodontia. Fossils we identify as cynodont incisors and caniniform teeth are cylindrical in cross-section and spatulate apically, with the taller surfaces interpreted as labial and the lower as lingual (NCSM 24726, Fig. 6.1). This morphology is common throughout Cynodontia (Hopson, 1971; Liu and Olsen, 2010; Sues and Hopson, 2010). Wrinkled enamel such as described by Sues and Hopson (2010) in some teeth of Boreogomphodon is evident on the incisiform tooth illustrated here (e.g., Fig. 6.1b). Based on specimen size, we suspect that many of these are the anterior dentition of traversodontids, as most are too large to pertain to the specimens we assign to Microconodon but comparable in size to the traversodontid postcanines documented here. Diverse other morphotypes appear to represent additional cynodont taxa. Some of these bear a cingulum in addition to multiple cusps (e.g., Fig. 6.2-6.7, see below), but remain more primitive than those of typical Early Jurassic mammals in lacking cuspules on the cingula and other more complex features (e.g., Crompton and Luo, 1994; Luo et al., 2001) and the total diversity of the site may be higher, although probably not as high as the rich cynodont assemblage of the Saint-Nicolas-dePort locality in the uppermost Triassic of France (Godefroit and Battail, 1997), especially as we have only recovered approximately 22 incisiform, caniniform, and other fragments identifiable as cynodonts but not diagnostic of less inclusive clades.

\section{Family Traversodontidae Huene, 1936 (Huene 1935-1942) aff. Boreogomphodon Sues and Olsen, 1990}

Figure 6.2

Teeth we identify as traversodont most closely resemble the contemporaneous taxon Boreogomphodon jeffersoni Sues and Olsen (1990), first described from Late Triassic age strata of Virginia. We designate the more diagnostic postcanine teeth as gomphodont or sectorial, following Hopson (1971, see also Liu, 2007; Liu and Sues, 2010). The gomphodont teeth are molariform in shape (NCSM 24723, Fig. 6.2) while the sectorial teeth are spatulate (Fig. 6.3-6.6). The spatulate teeth are more prevalent in juveniles and may disappear in mature adults (Hopson, 1971). At least some appear similar to the Newark Supergroup species Boreogomphodon jeffersoni and distinct from another, apparently closely related, Newark species, Plinthogomphodon herpetairus (Sues and Olsen, 1990; Sues et al., 1999; Liu, 2007; Liu and Sues, 2010), although Sues and Hopson (2010, p. 1216) briefly noted that Plinthogomphodon may be synonymous with Boreogomphodon. Sues and Hopson (2010; see also Liu and Sues, 2010) recently rediagnosed $B$. jeffersoni but the character of the dentition they used to separate it from other taxa is "lower molariform postcanine tooth of all but the smallest individuals with three rather than two posterior cusps" (Sues and Hopson, 2010, p. 1205). Sues and Olsen (1990, p. 1021) also felt that "upper postcanine teeth with a single mesial buccal accessory cusp and a large mesial basin" were diagnostic of
Boreogomphodon. Similarly, Liu and Sues (2010) reported $B$. jeffersoni from a nearby, stratigraphically lower quarry in the Pekin Formation of Carnian age (Whiteside et al., 2011). Because most of the Moncure assemblage consists of very small bones and teeth, it is possible that the recovered molariform teeth simply represent teeth too small to record this diagnostic characteristic. Molariform teeth identified here (e.g., Fig. 6.2) are extremely similar to those illustrated by Sues and Hopson (2010, figs. 6, 7). We interpret NCSM 24723 (Fig. 6.2) as an upper left molariform very similar to that of Boreogomphodon jeffersoni as illustrated by Sues and Hopson (2010, fig. 7). Points of detailed similarity include the overall shape, presence of well-developed anterobuccal buccal cusps, a deep anterior basin, and well developed lateral cusp. Upper molariform teeth lack a buccal cingulum (e.g., Fig. 6.2a), similar to the condition in Boreogomphodon as described by Sues and Hopson (2010). The primary difference we find is that the Moncure specimen lacks the posterior buccal cusp found on Boreogomphodon. Still, this tooth is clearly less complex than the slightly younger Plinthogomphodon herpetairus Sues et al. (1999) as the buccal and lateral cusps in Boreogomphodon and the Moncure specimens are more uniform and lack the well-defined cuspules of Plinthogomphodon. Similarly, these teeth lack the transverse ridges of Menadon besairei and the labial expansion of Dadadon isaloi Flynn et al. (2000). They are also distinct from gomphodont cynodonts from Saint-Nicolas-de-Port, including both Maubeugia lotharingica and Rosieria delsatei Godefroit and Battail (1997).

The molariform teeth from Moncure are also distinct from the "traversodonts" and other cynodonts illustrated by Godefroit and Battail (1997) from the much younger SaintNicolas-de-Port locality in the uppermost Triassic of France. In particular, the molariform teeth described here have a deeper anterior basin between tall, well-defined buccal and labial cusps, and the cusps themselves are less subdivided, lacking the many cuspules that typify the Saint-Nicolas-dePort cynodonts.

There are several morphotypes of sectorial cynodont postcanine teeth from the Moncure locality (Fig. 6.3-6.6). Many of these resemble those of Boreogomphodon (Sues and Olsen, 1990; Sues and Hopson, 2010) and Plinthogomphodon (Sues et al., 1999). Sectorial teeth from Moncure are tri-, tetraor pentacuspate, with the second cusp always the largest. The cusps are generally aligned mesio-distally, although the first cusp may be deflected lingually in tetra- and pentacuspate crowns (e.g., NCSM 25174, Fig. 6.6). The presence of this anterolingual cusp differs from other specimens of Boreogomphodon (Sues, personal commun.). Most of these teeth are asymmetrical in occlusal view with a more or less straight lingual margin and a bulging labial margin that forms a bulbous base and that may bear a small, low, accessory cusplet (NCSM 24749, Fig. 6.4; NCSM 23569, Fig. 6.5). Some crowns are relatively tall, with the height of the second cusp as tall or taller than the tooth is mesiodistally long (e.g., NCSM 24722, Fig. 6.3, possibly 6.6, 6.7), whereas in others it is low, with crown height as little as half the crown length in extreme cases (Fig. 6.4, 6.5). Most of the teeth we illustrate are only lightly worn, although a few small wear facets are apparent (e.g., Fig. 6.5a, 6.5c) and most damage is instead attributed to taphonomic factors. This lack of wear, combined with the small size of the specimens, suggests that many of these teeth pertain to juveniles. We have only recovered approximately 16 postcanine traversodont teeth. 


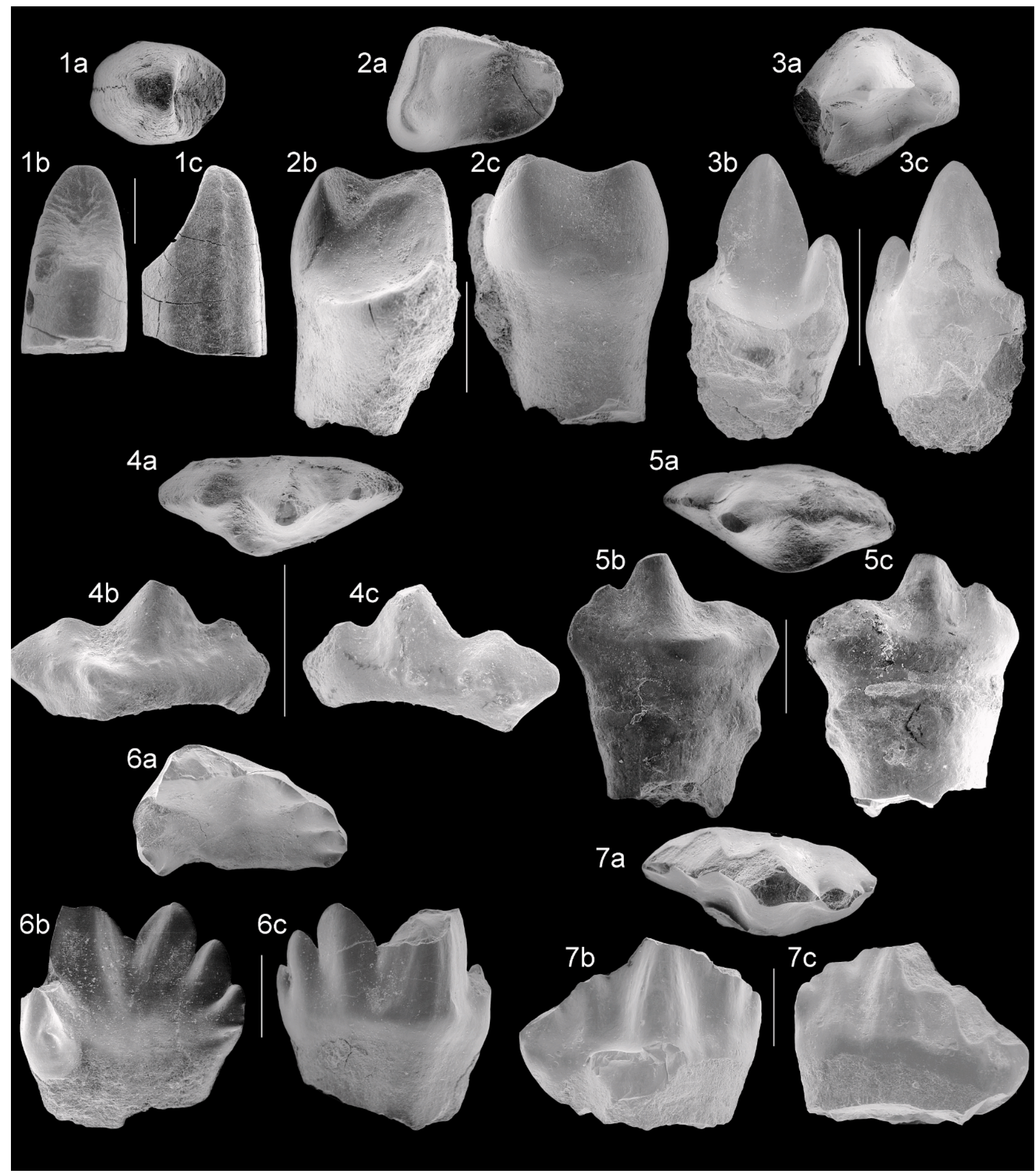

FIGURE 6-Scanning electron micrographs of "traversodont" cynodont teeth from the Moncure locality, Cumnock Formation, North Carolina. 1 , incisor (NCSM 24726) in occlusal (a), distal (b), and side (labial or lingual) views; 2-7, aff. Boreogomphodon (2), all in occlusal (a), lingual (b) and labial (c) views; 2, gomphodont tooth (NCSM 24723); 3, sectorial tooth (NCSM 24722); 4, sectorial tooth (NCSM 24749); 5 , sectorial tooth (NCSM 23569); 6, sectorial tooth (NCSM 25174); 7, sectorial tooth (NCSM 23570). All scale bars $1 \mathrm{~mm}$. 
Suborder EuCYNODONTIA Kemp, 1982

Subdivision EUCYNODONTIA incertae sedis

Genus Microconodon Osborn, 1886

MICROCONODON sp.

Figure 7

Microconodon is the most common cynodont at the Moncure locality with well over 30 specimens represented by isolated teeth. Sues (2001) documented that the first two postcanine teeth in more complete specimens of Microconodon are relatively simple, laterally compressed crowns that may possess a distal swelling or accessory cusp. The next few positions (5-6) bear tricuspid teeth that, as described by Sues (2001) are sectorial and typically bear three mesio-distally aligned cusps, with the most posterior teeth occasionally possessing a fourth cusp. In all cases the second cusp is the largest, and all postcanines lack cingula. These teeth may also possess incipiently bifurcated roots, and this combination of attributes readily seen in numerous NCSM specimens (Fig. 7). We illustrate isolated specimens in Figure 7 but these represent the mesial (NCSM 23576, Fig. 7.1), mid-row (NCSM 24747, Fig. 7.2) and distal (NCSM 21649, 23560; Fig. 7.3, 7.4) postcanines as described by Sues (2001). Notably, the type locality of Microconodon also lies in the Cumnock Formation in the nearby Chatham Coal Field (Osborn, 1886; Simpson, 1926; Sues, 2001). Following Sues (2001), teeth we assign to Microconodon possess taller crowns and fewer (3-4) cusps than those assigned to Pseudotriconodon wildi by Godefroit and Battail (1997). Other key features of Microconodon include a carina ("cutting edge" of Sues, 2001) on both edges of the principal cusp as well as the facing portions of the accessory cusps, whereas Pseudotriconodon has carinae on all cusps.

The teeth we assign to Microconodon here are generally less complex than those of advanced cynodonts and/or primitive mammals known from uppermost Triassic sites in France (Saint-Nicolas-de-Port, Varangéville), Belgium (Gaumé, Habay-la-Vielle, Attert), Luxembourg (Medernach) (Hahn et al., 1984, 1987, 1988; Godefroit and Sigogneau-Russell, 1995; Godefroit, 1997; Godefroit and Battail, 1997) and Germany (Lucas et al., 2001). That is, the Microconodon teeth are relatively simple with the cusps all aligned mesio-distally and lacking any sort of cingulum. Godefroit and SigogneauRussell $(1995$, pl. 1, 6, 7) illustrated broadly similar teeth from Varangéville that they assigned to ?Dromatheriidae and Chiniquodontoidea indet (as well as another polycuspate tooth they assigned to aff. Eudimorphodon). Other synapsids from Varangéville posses more cusps, cingula, and more complicated molariform teeth.

The presence of an incipiently bifurcated root and tooth crowns that are generally asymmetrical in labial view distinguish these teeth from Pseudotriconodon wildi Hahn et al. 1984 and Gaumia (Hahn et al., 1987; Godefroit and Sigogneau-Russell, 1995; Godefroit and Battail, 1997). They are superficially similar to Tricuspes but lack the slight curvature (lingual margin concave in occlusal view, see Godefroit and Battail, 1997, fig. 6b) and the tiny posterior accessory cusp. They also have a taller crown (crown length:height 1) than Tricuspes, Lepagia gaumensis Hahn et al. (1987) or Meurthodon gallicus Godefroit and Battail (1997). The cusps are much more coalesced in the Moncure specimens than in Meurthodon or Tricuspes, and more distinct than in Hahnia or Gaumia (Godefroit and Battail, 1997, figs. 7, $8,10,11,13-15)$. They are more laterally compressed and lack the cingula and cuspules of the mammal-like tooth from the upper Lehrbergschichten of Geissgurgelbach, Germany (Lucas et al., 2001).

Some teeth we refer to cynodonts, particularly those of Microconodon, are superficially similar to the teeth of basal pterosaurs, especially Eudimorphodon (e.g., Wild, 1978). As Godefroit and Cuny (1997) demonstrated, however, most sectorial cynodont teeth are more strongly laterally compressed (TCL/TCW 2.4) and lack the baso-apical striations that typify most Eudimorphodon species, so we are comfortable assigning these teeth to various cynodont taxa and not to archosaurs or other polycuspate taxa such as Tanystropheus (Wild, 1973), or Trilophosaurus (Heckert et al., 2006).

\section{TRACE FOSSILS}

A common component of microvertebrate accumulations are evidence of remains ingested by larger vertebrates. Most commonly, this evidence takes the form of coprolites, but damaged bones and teeth can also indicate ingestion, if not actual predation, of microvertebrate taxa by larger vertebrates. We illustrate here a small coprolite (NCSM 25720, Fig. 2.17). Although the Moncure site yields hundreds of coprolites, most are relatively small, and they also tended to "float" with the waste rock during heavy liquid separation. Still, as a whole they are smaller and less common than at many broadly contemporaneous microvertebrate sites such as the Placerias quarry (Kaye and Padian, 1994) or those in the Petrified Forest National Park (Murry, 1989; Heckert, 2004). We also illustrate a representative archosauriform tooth lacking enamel (NCSM 25719, Fig. 2.15). The tooth is relatively low and bulbous and its shape resembles teeth we refer to Revueltosaurus olseni here. It is just one of many (more than two dozen of similar morphology) enamel-less teeth recovered from the site. Crenulations along the margins probably conform to the original position of denticles. Taphonomic studies have demonstrated that the long residence time in the digestive tract of modern crocodilians (and therefore probably more basal archosauriforms) can strip the enamel from ingested teeth (Fisher, 1981), and Heckert (2004) reported similar preservation of some teeth in microvertebrate assemblages from Late Triassic age strata of Texas, New Mexico, and Arizona. We note here that this particular tooth preserves a resorbtion pit, suggesting that it was either shed and subsequently ingested by its owner or, less likely, was ingested by another organism after loss by its owner.

\section{DISCUSSION}

Although the majority of the identifiable taxa from Moncure are tetrapods, the overall assemblage is dominated by aquatic taxa, principally osteichthyans. Indeed, approximately $90 \%$ of the fossils recovered clearly pertain to actinopterygians. Even by "weighting" other remains such that 100 scales are equivalent to one other identifiable element (following Heckert, 2004), the majority of the recovered fossils clearly pertain to fish and other aquatic taxa. Thus, the site is as dominated by aquatic taxa as oxbow lake localities described by Heckert (2004) from Late Triassic age strata of the American southwest. Of course, the majority of osteichthyan-dominated assemblages in the Newark Supergroup are truly lacustrine (perennial lake) assemblages characterized by more complete fish skeletons (e.g., Bock, 1959; Olsen et al., 1982; McCune et al., 1984). For example, Schaeffer and MacDonald (1978) and Olsen et al. (1982) reviewed, but did not illustrate, the osteichthyans of the Deep River Basin, concluding that almost all records were from the Cumnock Formation and that the most diagnostic fossils were best 


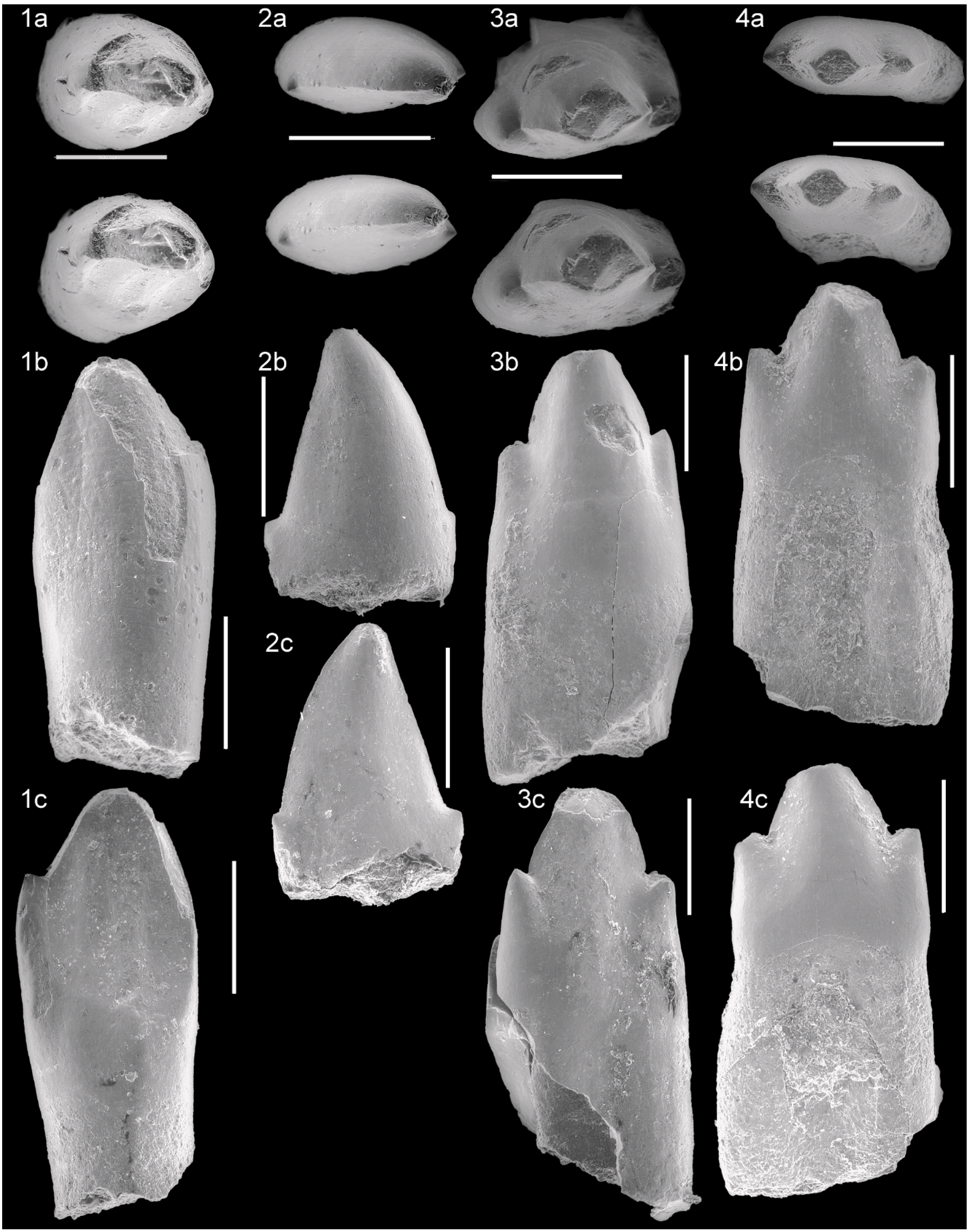

FIGURE 7-Scanning electron micrographs of representative postcanine teeth tentatively assigned to Microconodon sp. from the Moncure locality, Cumnock Formation, North Carolina. All are in stereo occlusal (a), lingual $(b)$ and labial $(c)$ views. 1, anterior postcanine (NCSM 23576); 2, anterior postcanine (NCSM 24747); 3, posterior postcanine (NCSM 21649); 4, posterior postcanine (NCSM 23560). Scale bars $500 \mu \mathrm{m}$. 
assigned to the redfieldiids Cionichthys and Synorichthys sp., although they also reported scales they assigned to the coelacanth Diplurus (see also Schaeffer, 1954). However, the incomplete nature of the screenwashed Moncure elements hinders direct comparison to the assemblages documented by Schaeffer and MacDonald (1978) for the Deep River Basin or even Triassic fish assemblages from the American West (Schaeffer, 1967; Huber et al., 1993b; Milner et al., 2006).

There are relatively few Newark Supergroup localities that are taphonomically and taxonomically similar to the Moncure site. Prior to the 1980s, very little was known about small Triassic vertebrates, as almost no systematic screenwashing projects had been undertaken, and thus the best-known taxa came either from European fissure fills or the occasional discovery of small skeletal remains in traditional excavations. However, this knowledge has expanded greatly due in large part to extensive screenwashing efforts in Late Triassic age strata of the American Southwest (e.g., Murry, 1986; Kaye and Padian, 1994; Heckert, 2004), further excavations at more sites, particularly Saint-Nicolas-de-Port in Europe (Godefroit and Battail, 1997; Godefroit and Cuny, 1997 and references cited therein) and the Carnian age Tomahawk locality in Virginia (Sues et al., 1994; Olsen and Johansson, 1994), as well as more work on the fissure fills in the United Kingdom (e.g., Fraser, 1994) and other sites. Thus, reviews by Fraser (2006) and Sues and Fraser (2010) and now populated by a much more diverse cast of small vertebrates than would have been possible just two decades ago.

Still, comparisons are difficult. Within the Newark Supergroup, the Tomahawk locality is the only site that appears similar in facies and collecting technique to the Moncure locality, as it is the only Late Triassic age site with a published screenwashed microvertebrate fauna (e.g., Sues and Olsen, 1990, 1993; Sues, 1991; Olsen and Johansson, 1994; Sues et al., 1994). Similarities between the Tomahawk and Moncure sites include the presence of abundant redfieldiids, as well as the tetrapod taxa Uatchitodon, Boreogomphodon, and Microconodon and at least some lepidosauromorphs. Differences include more semionotiforms, lungfish, lepidosauromorphs, and Revueltosaurus, Colognathus, Crosbysaurus, and possibly, a more diverse archosauriform assemblage at Moncure, whereas the slightly older (Carnian) Tomahawk locality includes abundant hybodont chondrichthyans, rare procolophonids or related taxa (Gomphosauridion and Xenodiphyodon) as well as the unusual archosauriform Euscolosuchus. Both localities appear to represent lacustrine or lacustrine-margin facies as described by Olsen and Johansson (1994). Thus, the faunal differences evident here may be real, although the microvertebrates from the Tomahawk locality are still not fully described.

Comparison with other Newark Supergroup localities is less direct. Some nineteenth century localities that are also in the Deep River Basin (e.g., Emmons, 1856; Osborn, 1886) are either inaccessible or were excavated using traditional methods so that only larger vertebrates were collected (Olsen et al., 1991). Similarly, some other localities, such as the nearby slightly younger Triangle Brick quarry near Genlee, North Carolina, represent fortuitous occurrences of tetrapods, some of which are gut contents of larger taxa (Sues et al., 1999, 2003; Peyer et al., 2008). Although fish and marginal lacustrine microvertebrate assemblages amenable to screenwashing do occur at the Genlee site (Olsen, 1977; Olsen et al., 2001; Sues et al., 2001; Whiteside et al., 2011), these have yet to be described. Thus, the Moncure assemblage appears somewhat unique in the Deep River Basin in that it is not dominated by large archosaurs and temnospondyls but this probably reflects sampling and facies differences as much as any other factors.

The Lagerstätten of the Virginia Solite quarry in the Cow Branch Formation on the North Carolina-Virginia border also yield abundant fish and small tetrapods and insects (Olsen et al., 1978; Olsen, 1979; Fraser et al., 1996, 2007; Casey et al., 2007; Blagoderov et al., 2007), but represent totally different, completely aquatic environments. Consequently, the fauna of the Virginia Solite quarries is distinct from that of the Moncure locality, and indeed consists of many taxa thus far restricted to Newark perennial lake deposits (e.g., Tanytrachelos; Olsen, 1988) or else endemic to a single basin (Mecistotrachelos). Because the sediments at the Virginia Solite quarry have experienced alteration associated with lowgrade metamorphism, they have not been amenable to screenwashing so, even if facies similar to Moncure or the Tomahawk locality are identified there, it appears unlikely that it will yield a similar fauna just because of the difficulty of obtaining isolated small vertebrates from these facies.

As noted previously, the Moncure assemblage is somewhat similar to typical microvertebrate assemblages of Late Triassic age, especially those from "wetter" paleoenvironments such as the Placerias quarry (Kaye and Padian, 1994) or "Dying Grounds" (Murry, 1989; Heckert, 2004). Commonalities include abundant osteichthyans and numerous, diverse archosauromorphs, including shared taxa such as Crosbysaurus and Uatchitodon. Similarly, Colognathus is known from several microvertebrate localities in Texas and New Mexico (Heckert, 2004, 2006). However, Moncure differs from these localities in that most aquatic Chinle sites include abundant hybodont and/or xenacanthid chondrichthyans, which are absent at Moncure, and cynodonts are much less common in the Chinle than they are at Moncure.

Extending comparisons across Late Triassic age localities is only really possible in Laurasia. To date, almost all localities of Late Triassic age in Gondwana only occasionally yield small tetrapods, and there are no published Gondwanan screenwashed microvertebrate assemblages. In comparison to the various fissure fills in the United Kingdom (e.g., Fraser, 1994; Whiteside and Marshall, 2008), Moncure is definitely more aquatic, which is hardly surprising, given the relatively terrestrial nature of many fissure fills. Screenwashing material rather than preparing and/or dissolving small blocks may account for some of the differences between the fragmentary lepidosaurs of Moncure and the more complete fossils found in many fissures but both types of sites do preserve small lepidosaurs, including sphenodontians. Mammals and highly derived cynodonts are more common in the fissure fills but this may be partly because most are thought to be much younger (Rhaetian to Early Jurassic) than Moncure.

Although we have collected fewer fossils than are known from Saint-Nicolas-de-Port (Godefroit and Battail, 1997; Godefroit and Cuny, 1997 and references cited within), the Moncure locality preserves at least as much archosauriform diversity as Saint-Nicolas-de-Port, but does not seem to contain the same diversity of synapsids. Increased sampling may change this, as many of the cynodont taxa at SaintNicolas-de-Port are known from only a few, or even just one, tooth (Godefroit and Battail, 1997) but for now it appears that these differences are real.

\section{CONCLUSIONS}

The descriptions we provide here illustrate a remarkably diverse assemblage, including redfieldiids, semionotids, dipnoans, 
temnospondyls, lepidosaurs, and diverse archosauriforms and cynodonts. Moncure is therefore one of the richer Triassic assemblages known from the Newark Supergroup (eight taxa diagnostic to the generic level, and numerous other, less inclusively diagnostic forms), and appears comparable to the older (Carnian) Tomahawk locality in the Vinita Formation of Virginia (Sues et al., 1994; Whiteside et al., 2011) and at least as rich as the older (also Carnian) Wolfville Formation localities in Nova Scotia (Olsen, 1988). Compared to assemblages in the American Southwest (e.g., Murry, 1989; Heckert, 2004), the Moncure fauna appears similar in terms of most so-called "lower vertebrates" (osteichthyans, amphibians, diapsids) but lacks sharks entirely and has cynodonts, which are exceptionally scarce in the American Southwest. Particularly important occurrences we document here include the first record of lungfish from the Newark Supergroup, a diverse archosauriform assemblage that includes enigmatic taxa (Galtonia, Crosbysaurus, Revueltosaurus) and the rare venomous form Uatchitodon, and multiple cynodonts closely allied to Boreogomphodon and the highly derived cynodont Microconodon. The large number of cynodont remains also fits with the locality's near-equatorial position during the Late Triassic, where apparently cynodonts were abundant compared with contemporaneous higher, tropical and subtropical latitudes in which cynodonts are uncommon (Whiteside et al., 2011). The high diversity of both the cynodonts and archosauriforms is similar to some European assemblages, most notably SaintNicolas-de-Port (Godefroit and Battail, 1997; Godefroit and Cuny, 1997), which were at temperate latitudes during the latest Triassic, where more humid climates prevailed much like the Triassic equatorial tropics.

Many taxa from Moncure and comparable localities are known only from teeth, but these assemblages still provide great insight into the diversity of small tetrapods during Late Triassic time. Although these isolated teeth may be enigmatic, the taxonomic history of Revueltosaurus demonstrates that there is value in identifying unique tooth morphotypes, even of non-mammalian amniotes. In the case of Revueltosaurus, the description of isolated teeth from multiple localities not only provided a basis for biostratigraphy (e.g., Hunt, 1989a; Padian, 1990; Heckert, 2002), but when additional materials were discovered (Parker et al., 2005), the distribution of this taxon was already well established. Thus, description of these new assemblages can presage the distribution of taxa. Furthermore, the diverse assemblage described here amply demonstrates that screenwashing for microvertebrates can greatly increase the known faunal diversity even in a wellknown depositional system such as the Newark Supergroup.

\section{ACKNOWLEDGMENTS}

We are indebted to the company that has granted access to the quarry, although they wish to remain anonymous. Numerous museum staff and volunteers assisted one of us (VS) in collecting fossils at Moncure. An Appalachian State University Research Council grant provided support for the microvertebrate laboratory work, and Undergraduate Research Assistantships from both the Department of Geology and Office of Undergraduate Research supported JSM. SEM work was conducted at the ASU College of Arts and Sciences Microscopy Facility with assistance from G. Huo and S. Hageman. Collections staff at YPM provided casts of Revueltosaurus olseni and confirmed its catalog number. We thank H.-D. Sues for advice on the identification of the synapsids. Reviewers N. C. Fraser and W. G. Parker provided useful comments on an earlier draft of this manuscript.

\section{REFERENCES}

Alcober, O. 2000. Redescription of the skull of Saurosuchus galilei (Archosauria: Rauisuchidae). Journal of Vertebrate Paleontology, 20:302-316.

Anderson, J. S., R. R. Reisz, D. Scott, N. B. Fröbisch, AND S. S. SUMIDA. 2008. A stem batrachian from the early Permian of Texas and the origin of frogs and salamanders. Nature, 453:515-518.

Arambourg, C. AND L. Bertin. 1958. On the fossil fishes found by $\mathrm{Mr}$. Gardner in the Province of Ceara, in the north of Brazil. Edinburgh New Philosophical Journal, 30:82-84.

BASZIO, S. 2008. Information from microvertebrate localities: Potentials and limits, p. 3-8. In J. T. Sankey and S. Baszio (eds.), Life of the Past. Indiana University Press, Bloomington.

Bengston, P. 1988. Open nomenclature. Palaeontology, 31:223-227.

BENTON, M. J. 1985. Classification and phylogeny of the diapsid reptiles. Zoological Journal of the Linnean Society, 84:97-164.

Benton, M. J. 2005. Vertebrate Palaeontology. Unwin Hyman, London, $455 \mathrm{p}$.

BERG, L. S. 1940. Classification of fishes both recent and fossil. Transactions of the Zoological Academy of Sciences, U.S.S.R., 5:85517.

Blagoderov, V., D. A. Grimaldi, and N. C. Fraser. 2007. How time flies for flies: Diverse Diptera from the Triassic of Virginia and early radiation of the order Diptera. American Museum Novitates, 3572, $39 \mathrm{p}$.

Bock, W. 1959. New eastern American Triassic fishes and Triassic correlations. Geological Center Research Series, 1, 184 p.

BRoOM, R. 1905. Notice of some new fossil reptiles from the Karroo beds of South Africa. Records of the Albany Museum, 1:331-337.

Brusatte, S. L., M. J. Benton, J. B. Desojo, And M. C. Langer. 2010. The higher-level phylogeny of Archosauria (Tetrapoda: Diapsida). Journal of Systematic Palaeontology, 8:3-47.

Campbell, M. R. And K. K. Kimball. 1923. The Deep River coal field of North Carolina. North Carolina Geological and Economic Survey Bulletin, 33, 1-95 p.

CASE, E. C. 1921. A new species of Ceratodus from the Upper Triassic of Western Texas. Occasional Papers of the Museum of Zoology, University of Michigan, 101:1-2.

CASE, E. C. 1928. Indications of a cotylosaur and of a new form of fish from the Triassic beds of Texas, with remarks on the Shinarump Conglomerate. Contributions of the Museum of Paleontology, University of Michigan, 3:1-14.

CASE, E. C. 1933. Colognathus proposed for Xenognathus, preoccupied. Journal of the Washington Academy of Sciences, 23:65.

CASEY, M. M., N. C. Fraser, AND M. KowAlEWSKi. 2007. Quantitative taphonomy of a Triassic reptile Tanytrachelos ahynis from the Cow Branch Formation, Dan River Basin, Solite Quarry, Virginia. Palaios, 22:598-611.

Cavin, L., V. Suteethorn, E. Buffetaut, And H. Tong. 2007. A new Thai Mesozoic lungfish (Sarcopterygii, Dipnoi) with an insight into post-Palaeozoic dipnoan evolution. Zoological Journal of the Linnean Society, 149:141-177.

ChatterJee, S. 1985. Postosuchus, a new thecodontian reptile from the Triassic of Texas and the origin of tyrannosaurs. Philosophical Transactions of the Royal Society of London, B, 309:395-460.

Cifelli, R. L., S. K. MADSEN, AND E. M. LARSON. 1996. Screenwashing and associated techniques for the recovery of microvertebrate fossils. Oklahoma Geological Survey Special Publications, 96-4:1-24.

CoOper, J. S. AND D. F. G. PoOLE. 2009. The dentition and dental tissues of the agamid lizard, Uromastyx. Journal of Zoology, 169:85-100.

CopE, E. C. 1869. Synopsis of the extinct Batrachia, Reptilia, and Aves of North America. Transactions of the American Philosophical Society, 14:252.

COPE, E. D. 1878. On some saurians found in the Triassic of Pennsylvania, by C.M. Wheatley. Proceedings of the American Philosophical Society, $17: 177$

CORNET, B. 1993. Applications and limitations of palynology in age, climatic, and paleoenvironmental analyses of Triassic sequences in North America. New Mexico Museum of Natural History and Science Bulletin, 3:75-93.

Crompton, A. W. AND Z. Luo. 1994. Relationships of the Liassic mammals Sinoconodon, Morganucodon oehleri, and Dinnetherium, p. 30-44. In F. S. Szalay, M. J. Novacek, and M. C. McKenna (eds.), Mammal Phylogeny: Mesozoic Differentiation, Multituberculates, Monotremes, Early Therians, and Marsupials. Springer-Verlag, New York.

Currie, P. J., J. K. Rigby, JR., And R. E. Sloan. 1990. Theropod teeth from the Judith River Formation of southern Alberta, Canada, p. 108-125. In K. Carpenter and P. J. Currie (eds.), Dinosaur 
Systematics: Approaches and Perspectives. Cambridge University Press, Cambridge.

DAtTA, P. M. AND S. RAY. 2006. Earliest lizard form the Late Triassic (Carnian) of India. Journal of Vertebrate Paleontology, 26:795-800.

Davidow-Henry, B. 1989. Small metoposaurid amphibians from the Triassic of western North America and their significance, p. 278-292. In S. G. Lucas and A. P. Hunt (eds.), Dawn of the Age of Dinosaurs in the American Southwest. New Mexico Museum of Natural History, Albuquerque.

DZIK, J. 2003. A beaked herbivorous archosaur with dinosaur affinities from the early Late Triassic of Poland. Journal of Vertebrate Paleontology, 23:556-574.

EMmONS, E. 1857. American geology, part VI. Sprague, Albany.

Evans, S. E. AND M. Borsuk-BIALYNICKA. 2009. The Early Triassic stem frog Czatkobatrachus from Poland. Palaeontologia Polonica, 65:79-106

EvanS, S. E. AND M. E. H. JoNES. 2010. The origin, early history and diversification of lepidosauromorph reptiles, p. 27-44. In S. Bandyopadhyay (ed.), Aspects of Mesozoic Biodiversity. Vol. 132. SpringerVerlag, Berlin

Evans, S. E. AND D. SigogneAu-Russell. 2001. A stem-group caecilian (Lissamphibia: Gymnophiona) from the Lower Cretaceous of North Africa. Palaeontology, 44:259-273.

Farlow, J. O., D. Brinkman, W. L. Abler, AND P. J. Currie. 1991. Size, shape, and serration density of theropod dinosaur lateral teeth. Modern Geology, 16:161-198.

Ferigolo, J. AND M. C. LANGER. 2007. A Late Triassic dinosauriform from south Brazil and the origin of the ornithischian predentary bone Historical Biology, 19:23-33.

FISHER, D. C. 1981. Crocodilian scatology, microvertebrate concentrations, and enamel-less teeth. Paleobiology, 7:262-275.

FlynN, J. J., S. J. Nesbitt, J. M. PARrish, L. Ranivoharimanana, AND A. R. WYss. 2010. A new species of Azendohsaurus (Diapsida:Archosauromorpha) from the Triassic Isalo Group of southwestern Madagascar: cranium and mandible. Palaeontology, 53:669-688.

FlynN, J. J., J. M. PARRish, B. RaKotosamimanana, L. RanivohaRIMANANA, W. F. SimPSON, AND A. R. WYSS. 2000. New traversodontids (Synapsida: Eucynodontia) from the Triassic of Madagascar. Journal of Vertebrate Paleontology, 20:422-427.

FrAAS, E. 1889. Die Labyrinthodonten aus der Schwabischen Trias. Palaeontographica, 36:1-158.

Fraser, N. C. 1994. Assemblages of small tetrapods from British Late Triassic fissure deposits, p. 214-226. In N. C. Fraser and H.-D. Sues (eds.), In the Shadow of the Dinosaurs: Early Mesozoic Tetrapods. Cambridge University Press, Cambridge.

FrASER, N. C. 2000. Early Mesozoic terrestrial ecosystems: Faunal changes among vertebrates. Paleontological Society Papers, 6:115-140.

FraSER, N. C. 2006. Dawn of the Dinosaurs: Life in the Triassic. Indiana University Press, Bloomington, $307 \mathrm{p}$.

Fraser, N. C. AND C. G. Shelton. 1988. Studies of tooth implantation in fossil tetrapods using high-resolution X-radiography. Geological Magazine, 125:117-122.

Fraser, N. C., D. A. Grimaldi, P. E. Olsen, And B. Axsmith. 1996. A Triassic lagerstätte from eastern North America. Nature, 380:615-619.

Fraser, N. C., P. E. Olsen, A. C. DoOley JR., AND T. R. Ryan. 2007. A new gliding tetrapod (Diapsida:?Archosauromorpha) from the Upper Triassic (Carnian) of Virginia. Journal of Vertebrate Paleontology, 27:261-265.

Furin, S., N. Preto, M. Rigo, G. Roghi, P. Gianolla, J. L. Crowley, AND S. A. BowRING. 2006. High-precision U-Pb zircon age from the Triassic of Italy: Implications for the Triassic time scale and the Carnian origin of calcareous nannoplankton and dinosaurs. Geology, 34:10091012 .

Gardner, J. D., Z. Roček, T. Prikryl, J. G. Eaton, R. W. Blob, AND J. T. SANKEY. 2010. Comparative morphology of the ilium of anurans and urodeles (Lissamphibia) and a re-assessment of the anuran affinities of Nezpercius dodsoni Blob et al., 2001. Journal of Vertebrate Paleontology, 30:1684-1696.

GAUTHIER, J. 1984. A cladistic analysis of the higher systematic categories of the Diapsida. University of California, Berkeley, $564 \mathrm{p}$.

Gauthier, J., R. Estes, And K. DE Quieroz. 1988. A phylogenetic analysis of Lepidosauromorpha, p. 15-98. In R. Estes and G. Pregill (eds.), Phylogenetic Relationships of the Lizard Families. Stanford University Press, Stanford.

GILL, T. 1872. On the homologies of the shoulder girdle of the dipnoans and other fishes. Annals and Magazine of Natural History, 11:173-178.

Godefroit, P. 1997. Reptilian, therapsid and mammalian teeth from the Upper Triassic of Varangéville (northeastern France). Bulletin de L'Institut Royal des Sciences Naturelles de Belgique, Sciences de La Terre, 67:83-102.
Godefroit, P. And B. Battail. 1997. Late Triassic cynodonts from Saint-Nicolas-de-Port (north-eastern France). Geodiversitas, 19:567631.

Godefroit, P. AND G. CUNY. 1997. Archosauriform teeth from the Upper Triassic of Saint-Nicolas-de-Port. Palaeovertebrata, 26:1-34.

Godefroit, P. AND D. Sigogneau-Russell. 1995/1996. Cynodontes et Mammiferes primitifs du Trias Superieur, en region Lorraine et Luxembourgeoise. Bulletin de la Société Belge de Géologie, 104:9-21.

GRANDE, L. 2010. An empirical synthetic pattern study of gars (Lepisosteiformes) and closely related species, based mostly on skeletal anatomy. The resurrection of Holostei. American Society of Ichthyologists and Herpetologists Special Publication, 6, $871 \mathrm{p}$.

HAECKEL, E. 1866. Generelle Morphologie der Organismen. Zweiter Band. Georg Reimer, Berlin, 462 p.

Hahn, G., J.-C. LePage, AND G. Wouters. 1984. Cynodontier-Zähne aus der Ober Trias von Medernach, Groosherzogtum Luxemburg. Bulletin de la Sociéte Belge de Géologie, 93:357-373.

HAHN, G., R. WILD, AND G. Wouters. 1987. Cynodontier-Zähne aus der Ober Trias von Gaume (S-Belgien). Mémoires pour servir á l'Explication des Cartes Géologiques et Minieres de la Belgique, 24:1-33.

HAHN, G., J. C. LePAGE, AND G. Wouters. 1988. Traversodonten-Zähne (Cynodontia) aus der Ober-Trias von Gaume (Sud-Belgien). Bulletin du Institut Royal des Sciences Naturelles de Belgique, Sciences de la Terre, $58: 177-186$.

Heckert, A. B. 2002. A revision of the Upper Triassic ornithischian dinosaur Revueltosaurus, with a description of a new species. New Mexico Museum of Natural History and Science Bulletin, 21:253-268.

Heckert, A. B. 2004. Late Triassic microvertebrates from the lower Chinle Group (Otischalkian-Adamanian: Carnian), southwestern U.S.A. New Mexico Museum of Natural History and Science Bulletin, $27,170 \mathrm{p}$.

HeCKeRT, A. B. 2005. Krzyzanowskisaurus, a new name for a probable ornithischian dinosaur from the Upper Triassic Chinle Group, Arizona and New Mexico. New Mexico Museum of Natural History and Science Bulletin, 29:77-83.

HeCKert, A. B. 2006. Geographic and stratigraphic distribution of the enigmatic Upper Triassic (Adamanian: Carnian) vertebrate fossil Colognathus obscurus Case. Museum of Northern Arizona Bulletin, $62: 155-156$

HeCKert, A. B. and S. G. LuCAS. 1997. First use of ornithischian dinosaurs for biostratigraphic zonation of the Upper Triassic Albertiana, 20:58-63.

Heckert, A. B. AND S. G. LuCAS. 2000. Taxonomy, phylogeny, biostratigraphy, biochronology, paleobiogeography, and evolution of the Late Triassic Aetosauria (Archosauria: Crurotarsi). Zentralblatt für Geologie und Paläontologie Teil I 1998 Heft, 11-12:1539-1587.

Heckert, A. B., S. G. Lucas, L. F. Rinehart, J. A. Spielmann, A. P. HUNT, AND R. KAHLE. 2006. Revision of the archosauromorph reptile Trilophosaurus, with a description of the first skull of Trilophosaurus jacobsi, from the Upper Triassic Chinle Group. West Texas, U.S.A. Palaeontology, 49:621-640.

Hopson, J. A. 1971. Postcanine replacement in the gomphodont cynodont Diademodon, p. 1-21. In D. M. Kermack and K. A. Kermack (eds.), Early Mammals. Vol. 50, London.

Hopson, J. A. AND J. W. KITCHING. 2001. A probainognathian cynodont from South Africa and the phylogeny of nonmammalian cynodonts. Bulletin of the Museum of Comparative Zoology, 156:5-35.

Huber, P., S. G. LuCAS, AND A. P. Hunt. 1993a. Revised age and correlation of the Upper Triassic Chatham Group (Deep River Basin, Newark Supergroup), North Carolina. Southeastern Geology, 33:171193.

Huber, P., S. G. LucAs, AND A. P. Hunt. 1993b. Late Triassic fish assemblages of the North American Western Interior. Museum of Northern Arizona Bulletin, 59:51-66.

HuEne, F. V. 1921. Reptilian and stegocephalian remains from the Triassic of Pennsylvania in the Cope collection. Bulletin of the American Museum of Natural History, 44:561-574.

HuEne, F. V. 1935-1942. Die fossilen Reptilien des südamerikanischen Gondwanalandes, ergebnisse der Sauriergrabungen in Südbrasilien 1928/29. C.H. Beck'Sche Verlagsbuchhandlung, Munich, 332 p.

Huene, F. V. 1936. Die fossilen Reptilien des südamerikanischen Gondwanalandes, ergebnisse der Sauriergrabungen in Südbrasilien 1928/29. C.H. Beck'Sche Verlagsbuchhandlung., Munich, 332 p.

Huene, F. V. 1946. Die grossen Stämme der Tetrapoden in den geologischen Zeiten. Biologisches Zentralblatt, 65:268-275.

HungerbüHLER, A. 2000. Heterodonty in the European phytosaur Nicrosaurus kapffi and its implications for the taxonomic utility and functional morphology of phytosaur dentitions. Journal of Vertebrate Paleontology, 20:31-48. 
HunT, A. P. 1989a. A new ?ornithischian dinosaur from the Bull Canyon Formation (Upper Triassic) of east-central New Mexico, p. 355-358. In S. G. Lucas and A. P. Hunt (eds.), Dawn of the Age of Dinosaurs in the American Southwest. New Mexico Museum of Natural History, Albuquerque.

Hunt, A. P. 1989b. Cranial morphology and ecology among phytosaurs, p. 349-354. In S. G. Lucas and A. P. Hunt (eds.), Dawn of the Age of Dinosaurs in the American Southwest. New Mexico Museum of Natural History, Albuquerque.

Hunt, A. P. 1993. Revision of the Metoposauridae (Amphibia: Temnospondyli) and description of a new genus from western North America. Museum of Northern Arizona Bulletin, 59:67-97.

Hunt, A. P. AND S. G. LuCAS. 1994. Ornithischian dinosaurs from the Upper Triassic of the United States, p. 227-241. In N. C. Fraser and H.-D. Sues (eds.), In the Shadow of the Dinosaurs: Early Mesozoic Tetrapods. Cambridge University Press, Cambridge.

HuXLEY, T. H. 1875. On Stagonolepis robertsoni, and on the evolution of the Crocodile. Proceedings of the Geological Society of London, $31: 423-438$.

HuXLEY, T. H. 1880. On the application on the laws of evolution to the arrangement of the Vertebrata and more particularly of the Mammalia. Zoological Society of London, Scientific Memoirs, 4:457-472.

Irmis, R. B., W. G. Parker, S. J. Nesbitt, AND J. LiU. 2007. Early ornithischian dinosaurs: the Triassic record. Historical Biology, 19:322.

JAEGER, G. F. 1828. Aber die fossilen Reptilien, welche in Würtemberg aufgefunden worden sind. Metzler, Stuttgart, $48 \mathrm{p}$.

JANVIER, P. 1996. Early vertebrates. Oxford University Press, Oxford, 33, $393 \mathrm{p}$.

JENKINS JR., F. A. 1970. Cynodont postcranial anatomy and the "prototherian" level of mammalian organization. Evolution, 24:230 252.

JoNES, M. E. H. 2008. Skull shape and feeding strategy in Sphenodon and other Rhynchocephalia (Diapsida: Lepidosauria). Journal of Morphology, 269:945-966.

Kammerer, C. F., S. J. Nesbitt, AND N. H. Shubin. 2011. The first basal dinosauriform (Silesauridae) from the Late Triassic of Morocco. Acta Palaeontologica Polonica, 56, in press.

Kaye, F. T. And K. Padian. 1994. Microvertebrates from the Placerias quarry: A window on Late Triassic vertebrate diversity in the American Southwest, p. 171-196. In N. C. Fraser and H.-D. Sues (eds.), In the Shadow of the Dinosaurs: Early Mesozoic Tetrapods. Cambridge University Press, Cambridge.

KEMP, A. 1998. Skull structure of post-Paleozoic lungfish. Journal of Vertebrate Paleontology, 18:43-63.

Kemp, T. S. 1982. Mammal-lie reptiles and the origin of mammals. Academic Press, London, 363 p.

KLEIN, E. F. 1885. Beiträge zur Bildung des Schädels der Knochenfische, 2. Jahreshefte des Vereins für Vaterländische Naturkunde in Württemberg, 42:205-300.

KreBS, B. 1974. Die Archosaurier. Die Naturwissenschaften, 61:17-24.

Langer, M. C., J. Ferigolo, AND C. L. Schultz. 2000. Heterochrony and tooth evolution in hyperodapedontine rhynchosaurs (Reptilia, Diapsida). Lethaia, 33:119-128.

LinNAEus, C. 1758. Systema Naturae. Salvius, Stockholm.

Litwin, R. J. AND S. R. AsH. 1993. Revision of the biostratigraphy of the Chatham Group (Upper Triassic), Deep River basin, North Carolina, USA. Review of Palaeobotany and Palynology, 77:75-95.

LIU, J. 2007. New traversodontid material from North Carolina, U.S.A. and the taxonomy and phylogeny of Traversodontidae (Synapsida: Cynodontia). Ph.D. Dissertation, Columbia University, New York, $444 \mathrm{p}$.

LiU, J. AND P. E. OlsEN. 2010. The phylogenetic relationships of Eucynodontia (Amniota: Synapsida). Journal of Mammalian Evolution, 17:151-176.

LiU, J. AND H.-D. SuES. 2010. Dentition and tooth replacement of Boreogomphodon (Cynodontia: Traversodontidae) from the Upper Triassic of North Carolina, U.S.A. Vertebrata PalAsiatica, 48:169-184.

LonG, R. A. AND P. A. MURRY. 1995. Late Triassic (Carnian and Norian) tetrapods from the southwestern United States. New Mexico Museum of Natural History and Science Bulletin, 4, $254 \mathrm{p}$.

LuCAS, S. G. AND P. Huber. 2003. Vertebrate biostratigraphy and biochronology of the nonmarine Late Triassic, p. 143-191. In P. M. LeTourneau and P. E. Olsen (eds.), The great rift valleys of Pangea in Eastern North America: Sedimentology, Stratigraphy, and Paleontology. Vol. 2. Columbia University Press, New York.

LuCAS, S. G. AND Z. LuO. 1993. Adelobasileus from the Upper Triassic of West Texas: The oldest mammal. Journal of Vertebrate Paleontology, 13:309-334.
Lucas, S. G., A. B. Heckert, J. D. Harris, D. Seegis, and R. Wild. 2001. Mammal-like tooth from the Upper Triassic of Germany. Journal of Vertebrate Paleontology, 21:397-399.

LuO, Z.-H., A. W. Crompton, AND A.-L. Sun. 2001. A new mammaliaform from the Early Jurassic and evolution of mammalian characteristics. Science, 292:1535-1540.

MARTIN, M. 1979. Arganodus atlantis et Ceratodus arganensis, deux nouveaux Dipneustes du Trias supérieur continental marocain. Comptes Rendus Academie des Sciences, Paris, Sciences de la Terre et des Planetes Ser. D, 289:89-92.

MCCunE, A. R. 1987. Towards the phylogeny of a species flock: Semionotid fishes from a lake deposit in the Early Jurassic Towaco Formation, Newark Basin. Peabody Museum of Natural History Bulletin, 43,109 p.

McCune, A. R., K. S. Thomson, And P. E. Olsen. 1984. Semionotid fishes from the Mesozoic great lakes of North America, p. 27-44. In A. A. Echelle and I. Kornfield (eds.), Evolution of Fish Species Flocks. University of Maine Press, Orono.

MiLneR, R. A. 1994. Late Triassic and Jurassic amphibians: Fossil record and phylogeny, p. 226-241. In N. C. Fraser and H.-D. Sues (eds.), In the Shadow of the Dinosaurs: Early Mesozoic Tetrapods. Cambridge University Press, Cambridge.

Milner, A. R. C., J. I. Kirkland, And T. A. Birthisel. 2006. The geographic distribution and biostratigraphy of Late Triassic-Early Jurassic freshwater fish faunas of the southwestern United States. New Mexico Museum of Natural History and Science Bulletin, 37:522-529.

Mitchell, J. S. AND A. B. HeCKeRT. 2010. The setup, use and efficacy of sodium polytungstate separation methodology with respect to microvertebrate remains. Journal of Paleontological Techniques, 7:1-12.

Mitchell, J. S., A. B. Heckert, AND H.-D. Sues. 2010. Grooves to tubes: Evolution of the venom delivery system in a Late Triassic "reptile". Naturwissenschaften, 97:1117-1121.

MÜLLER, J. 1844. Über den Bau und die Grenzen der ganoiden und über das natürliche System der Fische. Abhandlungen der Akademie der Wissenschaften zu Berlin, 1844:117-216.

MURRY, P. A. 1986. Vertebrate paleontology of the Dockum Group, western Texas and eastern New Mexico, p. 109-137. In K. Padian (ed.), The Beginning of the Age of Dinosaurs: Faunal Change Across the Triassic-Jurassic boundary. Cambridge University Press, Cambridge.

MurRY, P. A. 1989. Microvertebrate fossils from the Petrified Forest and Owl Rock Members (Chinle Formation) in Petrified Forest National Park and vicinity, Arizona, p. 249-277. In S. G. Lucas and A. P. Hunt (eds.), Dawn of the Age of Dinosaurs in the American Southwest. New Mexico Museum of Natural History, Albuquerque.

Muttoni, G., D. V. Kent, P. E. Olsen, P. D. Steffano, W. Lowrie, S. M. BERNASCONI, AND F. M. HeRnÁNDEZ. 2004. Tethyan magnetostratigraphy from Pizzo Mondello (Sicily) and correlation to the Late Triassic Newark astrochronological polarity time scale. Geological Society of America Bulletin, 116:1043-1058.

NesBitT, S. J. 2011. The early evolution of archosaurs: relationships and the origin of major clades. Bulletin of the American Museum of Natural History, 392, $292 \mathrm{p}$.

Nesbitt, S. J. AND M. R. Stocker. 2008. The vertebrate assemblage of the Late Triassic Canjilon quarry (Northern New Mexico, USA), and the importance of apomorphy-based assemblage comparisons. Journal of Vertebrate Paleontology, 28:1063-1072.

Nesbitt, S. J., R. B. Irmis, AND W. G. PARker. 2007. A critical reevaluation of the Late Triassic dinosaur taxa of North America. Journal of Systematic Palaeontology, 5:209-243.

Olsen, P. E. 1977. Stop 1: Triangle Brick Quarry, p. 59-60. In G. L. Bain and B. W. Harvey (eds.), Field Guide to the Geology of the Durham Triassic basin. Carolina Geological Society, Raleigh.

OlSEN, P. E. 1978. On the use of the term Newark for Triassic and Early Jurassic rocks of eastern North America. Newsletters on Stratigraphy, 7:90-95.

OlsEN, P. E. 1979. A new aquatic eosuchian from the Newark Supergroup (Late Triassic-Early Jurassic) of North Carolina and Virginia. Postilla, 176:1-14.

OlSEN, P. E. 1988. Paleontology and paleoecology of the Newark Supergroup (early Mesozoic, eastern North America), p. 185-230. In W. Manspeizer (ed.), Triassic-Jurassic Rifting: Continental Breakup and the Origin of the Atlantic Ocean and Passive Margins, Part A. Elsevier, Amsterdam.

OLSEN, P. E. 1997. Stratigraphic record of the early Mesozoic breakup of Pangea in the Laurasia-Gondwana rift system. Annual Review of Earth and Planetary Sciences, 25:337-401.

Olsen, P. E. AND P. Huber. 1997. Stop 3: Triangle Brick Quarry, p. 22 29. In T. W. Clark (ed.), TRIBI: Triassic Basin Initiative, abstracts with programs and field trip guidebook. Duke University, Durham. 
Olsen, P. E. And A. K. Johansson. 1994. Field guide to Late Triassic tetrapod sites in Virginia and North Carolina, p. 408-430. In N. C Fraser and H.-D. Sues (ed.), In the Shadow of the Dinosaurs. Cambridge University Press, Cambridge.

Olsen, P. E., A. J. Froehlich, D. L. Daniels, J. P. Smoot, and P. J. W Gore. 1991. Rift basins of early Mesozoic age, p. 142-170. In J. W Horton Jr. and V. A. Zullo (eds.), Geology of the Carolinas. Vol Carolina Geological Society 50th Anniversary Volume. University of Tennessee Press, Knoxville.

Olsen, P. E., A. R. MCCune, And K. S. Thomson. 1982. Correlation of the early Mesozoic Newark Supergroup by vertebrates, principally fishes. American Journal of Science, 282:1-44.

Olsen, P. E. AND E. C. RAINFORTH. 2003. The "age of dinosaurs" in the Newark basin, with special reference to the Hudson Valley. Geology of the Lower Hudson Valley, Albany, 59-176.

Olsen, P. E., C. L. Remington, B. Cornet, and K. S. Thomson. 1978. Cyclic change in Late Triassic lacustrine communities. Science, 201:729733

Olsen, P. E., V. Schneider, H.-D. Sues, J. G. Carter, And K. Peyer. 2001. Biotic provinciality of the Late Triassic equatorial humid zone Geological Society of America Abstracts with Programs, 33(2):A27.

Olsen, P. E., N. H. Shubin, And M. H. Anders. 1987. New Early Jurassic tetrapod assemblages constrain Triassic-Jurassic tetrapod extinction event. Science, 237:1025-1029.

OsBoRn, H. F. 1886. Observations upon the Upper Triassic mammals, Dromatherium and Microconodon. Proceedings of the Academy of Natural Sciences of Philadelphia, 38:359-363.

OsBorn, H. F. 1903. On the primary division of the Reptilia into two subclasses, Synapsida and Diapsida. Science, 17:275-276.

OWEN, R. 1860. On the orders of fossil and recent Reptilia, and their distribution in time. Report of the British Association for the Advancement of Science, 29:153-166.

OWEN, R. 1861. Palaeontology, or a systematic summary of extinct animals and their geological relations. Adam and Charles Black, Edinburgh, $463 \mathrm{p}$

PADIAN, K. 1990. The ornithischian form genus Revueltosaurus from the Petrified Forest of Arizona (Late Triassic: Norian; Chinle Formation). Journal of Vertebrate Paleontology, 10:268-269.

PARKER, W. G. 2007. Reassessment of the aetosaur 'Desmatosuchus' chamaensis with a reanalysis of the phylogeny of the Aetosauria (Archosauria: Pseudosuchia). Journal of Systematic Palaeontology, 5:41-68.

Parker, W. G., R. B. Irmis, S. J. Nesbitt, J. W. Martz, and L. S. BRowne. 2005. The Late Triassic pseudosuchian Revueltosaurus callenderi and its implications of the diversity of early ornithischian dinosaurs. Proceedings of the Royal Society of London, B, 272:963-969.

Peyer, K., J. G. Carter, H.-D. Sues, S. E. Novak, and P. E. Olsen. 2008. A new suchian archosaur from the Upper Triassic of North Carolina. Journal of Vertebrate Paleontology, 28:363-381.

REGAN, C. T. 1923. The skeleton of Lepisosteus, with remarks on the origin and evolution of the lower neopterygian fishes. Proceedings of the Zoological Society of London, 1923:445-461.

ReInemund, J. A. 1955. Geology of the Deep River Coal Field. United States Geological Survey Professional Paper, 246, 157 p.

RIEPPEL, O. 1994. The Lepidosauromorpha: An overview with special emphasis on the Squamata, p. 23-37. In N. C. Fraser and H.-D. Sues (eds.), In the Shadow of the Dinosaurs: Early Mesozoic Tetrapods Cambridge University Press, Cambridge.

Renesto, S. AND F. M. Dalla Vecchia. 2000. The unusual dentition and feeding habits of the prolacertiform reptile Langobardisaurus (Late Triassic, Northern Italy). Journal of Vertebrate Paleontology, 20:622627.

Romer, A. S. 1955. Herpetichthyes, Amphibioidei, Choanichthyes or Sarcopterygii. Nature, 176:126

SAwIN, H. J. 1945. Amphibians from the Dockum Triassic of Howard County, Texas. University of Texas Publication, 4401:361-399.

SCHAEFFER, B., 1954. Pariostegas, a Triassic coelacanth. Notulae Naturae, 261:1-5

SCHAEFFER, B. 1967. Late Triassic fishes from the western United States Bulletin of the American Museum of Natural History, 135:287-342.

SCHAEFFER, B. AND M. MAngus. 1970. Synorichthys sp. (Palaeonisciformes) and the Chinle-Dockum and Newark (Upper Triassic) fish faunas. Journal of Paleontology, 44:17-22.

SCHAEFFER, B. AND N. G. MCDONALD. 1978. Redfieldiid fishes from the Triassic-Liassic Newark Supergroup of eastern North America Bulletin of the American Museum of Natural History, 159:131-173.

SEELEY, H. G. 1895. Researches on the structure, organization, and classification of the fossil Reptilia, section 5. On the skeleton in new Cynodontia from the Karroo rocks. Philosophical Transactions of the Royal Society of London, Series B, 186:59-148.
SERENO, P. C. 1991. Basal archosaurs: phylogenetic relationships and functional implications. Society of Vertebrate Paleontology Memoir, 2, $53 \mathrm{p}$

Shubin, N. H., P. E. OlsEN, AND H.-D. SuEs. 1994. Early Jurassic small tetrapods from the McCoy Brook Formation of Nova Scotia, Canada, p. 242-250. In N. C. Fraser and H.-D. Sues (eds.), In the Shadow of the Dinosaurs: Early Mesozoic Tetrapods. Cambridge University Press, Cambridge.

SIMPSON, G. G. 1926. Are Dromatherium and Microconodon Mammals? Science, 63:548-549.

Soto, M. AND D. PereA. 2010. Late Jurassic lungfishes (Dipnoi) from Uruguay, with comments on the systematics of Gondwanan ceratodontiforms. Journal of Vertebrate Paleontology, 30:1049-1058.

SuES, H.-D. 1991. Venom-conducting teeth in a Triassic reptile. Nature, 351:141-143.

SuES, H.-D. 1992. A remarkable new armored archosaur from the Upper Triassic of Virginia. Journal of Vertebrate Paleontology, 12:142-149.

SuES, H.-D. 1996. A reptilian tooth with apparent venom canals from the Chinle Group (Upper Triassic) of Arizona. Journal of Vertebrate Paleontology, 16:571-572.

SuES, H.-D. 2001. On Microconodon, a Late Triassic cynodont from the Newark Supergroup of eastern North America. Bulletin of the Museum of Comparative Zoology, 156:37-48.

SUES, H.-D. 2003. An unusual new archosauromorph reptile from the Upper Triassic Wolfville Formation of Nova Scotia. Canadian Journal of Earth Sciences, 40:635-648.

Sues, H.-D. AND N. C. Fraser. 2010. Triassic Life on Land-The Great Transition. Columbia University, New York, 236 p.

SuEs, H.-D. AND J. A. Hopson. 2010. Anatomy and phylogenetic relationships of Boreogomphodon jeffersoni (Cynodontia:Gomphodontia) from the Upper Triassic of Virginia. Journal of Vertebrate Paleontology, 30:1202-1220.

SuES, H.-D. AND P. E. OLSEN. 1990. Triassic vertebrates of Gondwanan aspect from the Richmond Basin of Virginia. Science, 249:1020-1022.

SuES, H.-D. AND P. E. OlsEn. 1993. A new procolophonid and a new tetrapod of uncertain, possibly procolophonian affinities from the Upper Triassic of Virginia. Journal of Vertebrate Paleontology, 13:282-286.

Sues, H.-D., P. E. Olsen, And J. G. CARTER. 1999. A Late Triassic traversodont cynodont from the Newark Supergroup of North Carolina. Journal of Vertebrate Paleontology, 19:351-354.

Sues, H.-D., P. E. Olsen, J. G. Carter, And K. Peyer. 2001. A remarkable Triassic tetrapod assemblage from the Deep River Basin of North Carolina. Geological Society of America Abstracts with Programs, 33(2):A27.

Sues, H.-D., P. E. Olsen, J. G. Carter, and D. M. Scott. 2003. A new crocodylomorph archosaur from the Upper Triassic of North Carolina. Journal of Vertebrate Paleontology, 23:329-343.

Sues, H.-D., P. E. Olsen, AND P. A. Kroehler. 1994. Small tetrapods from the Upper Triassic of the Richmond basin (Newark Supergroup), Virginia, p. 162-170. In N. C. Fraser and H.-D. Sues (eds.), In the Shadow of the Dinosaurs: Early Mesozoic Tetrapods. Cambridge University Press, Cambridge.

WeEms, R. E. AND P. E. OlsEN. 1997. Synthesis and revision of groups within Newark Supergroup, eastern North America. Geological Society of America Bulletin, 109:195-209.

Whiteside, D. I. And J. E. A. Marshall. 2008. The age, fauna and palaeoenvironment of the Late Triassic fissure deposits of Tytherington, South Gloucestershire, U.K. Geological Magazine, 145:105-147.

Whiteside, J. H., D. S. Grogan, P. E. Olsen, AND D. V. Kent. 2011. Climatically driven biogeographic provinces of Late Triassic tropical Pangea. Proceedings of the National Academy of Science, 108:8972-8977.

WILD, R. 1973. Die Triasfauna der Tessiner Kalkalpen XXIII. Tanystropheus longobardicus (Bassani). Schwiezerische Paläontologicsh Abhandlungen, 95:1-162.

WILD, R. 1978. Die Flugsaurier (Reptilia, Pterosauria) aus der Oberen Trias von Cene bei Bergamo, Italien. Bollettino della Societá Paleontologica Italiana, 17:176-256.

Williston, S. W. 1925. The Osteology of the Reptiles. Harvard University Press, Cambridge, $300 \mathrm{p}$

WoOdward, A. S. 1890. The fossil fishes of the Hawkesbury Series at Gosford. Memoirs of the Geological Survey of New South Wales (Palaeontology), 4:1-56.

ZanNo, L. E. A. B. Heckert, S. E. KrZYZanowski, and S. G. LuCAS. 2002. Diminutive metoposaurid skulls from the Upper Triassic Blue Hills (Adamanian: latest Carnian) of Arizona. New Mexico Museum of Natural History and Science Bulletin, 21:121-125.

ZITTEL, K. A. V. 1887-1890. Handbuch der Paläontologie. Abteilung 1. Paläozoologie Band III. Vertebrata (Pisces, Amphibia, Reptilia, Aves), Oldenbourg, München and Leipzig.

ACCEPTED 27 SEPTEMBER 2011 